\title{
Hadal water biogeochemistry over the Izu-Ogasawara Trench observed with a full-depth CTD-CMS
}

\author{
Shinsuke Kawagucci ${ }^{1,2,3, *}$, Akiko Makabe ${ }^{2,3, *}$, Taketoshi Kodama ${ }^{4}$, Yohei Matsui ${ }^{2,3}$, Chisato Yoshikawa ${ }^{2,5}$, \\ Etsuro Ono $^{6, a}$, Masahide Wakita ${ }^{7}$, Takuro Nunoura ${ }^{3,8}$, Hiroshi Uchida ${ }^{6}$, and Taichi Yokokawa ${ }^{3,8}$ \\ ${ }^{1}$ Department of Subsurface Geobiological Analysis and Research (D-SUGAR), Japan Agency for Marine-Earth Science and \\ Technology (JAMSTEC), 2-15 Natsushima-cho, Yokosuka 237-0061, Japan \\ ${ }^{2}$ Research and Development Center for Submarine Resources (SRRP), Japan Agency for Marine-Earth Science and \\ Technology (JAMSTEC), 2-15 Natsushima-cho, Yokosuka 237-0061, Japan \\ ${ }^{3}$ Project Team for Development of New-Generation Research Protocol for submarine resources, Japan Agency for \\ Marine-Earth Science and Technology (JAMSTEC), 2-15 Natsushima-cho, Yokosuka 237-0061, Japan \\ ${ }^{4}$ Japan Sea National Fisheries Research Institute, Japan Fisheries Research and Education Agency, Niigata, \\ 5939-22 Suido-cho, Niigata 951-8121, Japan \\ ${ }^{5}$ Department of Biogeochemistry, Japan Agency for Marine-Earth Science and Technology (JAMSTEC), \\ 2-15 Natsushima-cho, Yokosuka 237-0061, Japan \\ ${ }^{6}$ Research and Development Center for Global Change (RCGC), Japan Agency for Marine-Earth Science and Technology \\ (JAMSTEC), 2-15 Natsushima-cho, Yokosuka 237-0061, Japan \\ ${ }^{7}$ Mutsu Institute for Oceanography, Japan Agency for Marine-Earth Science and Technology (JAMSTEC), \\ 690 Kitasekine, Mutsu 035-0022, Japan \\ ${ }^{8}$ Research and Development Center for Marine Biosciences, Japan Agency for Marine-Earth Science and Technology \\ (JAMSTEC), 2-15 Natsushima-cho, Yokosuka 237-0061, Japan \\ apresent address: Japan Meteorological Agency, 1-3-4 Otemachi, Tokyo 100-8122, Japan \\ *These authors contributed equally to this work.
}

Correspondence: Shinsuke Kawagucci (kawagucci@jamstec.go.jp) and Taichi Yokokawa (taichi.yokokawa@jamstec.go.jp)

Received: 22 March 2018 - Discussion started: 3 April 2018

Revised: 1 June 2018 - Accepted: 11 June 2018 - Published: 13 July 2018

\begin{abstract}
Full-depth profiles of hydrographic and geochemical properties at the Izu-Ogasawara Trench were observed for the first time using a CTD-CMS (conductivitytemperature-depth profiler with carousel multiple sampling) system. Additionally, comparative samplings were done at the northern Mariana Trench using the same methods. A well-mixed hydrographic structure below $7000 \mathrm{~m}$ was observed within the Izu-Ogasawara Trench. Seawater samples collected from this well-mixed hadal layer exhibited constant concentrations of nitrate, phosphate, silicate, and nitrous oxide as well as constant nitrogen and oxygen isotopic compositions of nitrate and nitrous oxide. These results agree well with previous observations of the Izu-Ogasawara hadal waters and deep-sea water surrounding the Izu-Ogasawara Trench. In turn, methane concentrations and isotopic compo-
\end{abstract}

sitions indicated spatial heterogeneity within the well-mixed hadal water mass, strongly suggesting a local methane source within the trench, in addition to the background methane originating from the general deep-sea bottom water. Sedimentary compound releases, associated with sediment resuspensions, are considered to be the most likely mechanism for generating this significant $\mathrm{CH}_{4}$ anomaly.

\section{Introduction}

The CTD-CMS (conductivity-temperature-depth profiler with carousel multiple sampling) system has been the most essential and fruitful device in the history of oceanography. Seawater sensing by CTD draws a continuous profile 
of the general hydrographic properties, while seawater sampling at multiple selected depths by the CMS allows a variety of subsequent analyses for chemical and biological properties. Cross-ocean observations with CTD-CMS, in some cases led by international programs such as WOCE (Siedler et al., 2001) and GEOTRACES (Cutter, 2013), have yielded datasets of comparable qualities and sufficient horizontal resolution that serve as a basis for us to paint the overall picture of the Earth's ocean. However, one blank gap remains in that picture - the hadal waters (deeper than $7000 \mathrm{~m}$ in this study (see Sect. 3.1) but usually 6000 or $6500 \mathrm{~m}$; Jamieson et al., 2010; Walting et al., 2013), due to the extreme pressure there and a lack of full-depth CTD-CMS systems.

The lack of full-depth CTD-CMS systems greatly limited seawater sampling-based analyses and therefore the analysis and understanding of the hadal water column compared to all other parts of the ocean, for which CTD-CMS data are available. Nevertheless, a small number of hadal sampling efforts, not using CTD-CMS, have been carried out over the years. For example, a pioneering work (Mantyla and Reid, 1978) collected a total of four hadal seawater samples from two stations in the southern Mariana Trench (MT) with a specially designed acoustic release device. Hydrographical properties (salinity, oxygen, and nutrients) of the samples obtained demonstrated that hadal and abyssal waters exhibit identical characteristics.

At a trench axis station AN1 $\left(29^{\circ} 05 \mathrm{~N}-142^{\circ} 51 \mathrm{E} ; 9750 \mathrm{~m}\right)$ located in the mid Izu-Ogasawara Trench (IOT), vertical seawater samples were collected during two cruises of R/V Hakuho-maru in 1984 and 1994 (Nozaki et al., 1998; Gamo and Shitashima, 2018), by directly attaching standard Niskin bottles to a wire line. The samples were used to determine hydrographic properties and for ${ }^{222} \mathrm{Rn}$ analyses, while three specially designed samplers were also used for metals and other radionuclides analyses. The hadal water at AN1 exhibited vertically constant profiles in salinity, dissolved oxygen, nitrate, and phosphate, confirming the characteristics previously observed in the southern MT (Mantyla and Reid, 1978). The renewal time of the trench-filling hadal water was evaluated to be $\sim 5$ years from the distribution of radionuclides (Nozaki et al., 1998). Manganese and iron were slightly enriched in the hadal water only and were background level in the overlying abyssal water while significant ${ }^{222} \mathrm{Rn}$ excess was detected in waters up to $\sim 2700 \mathrm{~m}$ above the trench axis seafloor, suggesting lateral ${ }^{222} \mathrm{Rn}$ supply from the surrounding trench slope (Gamo and Shitashima, 2018). These hadal-water-specific characteristics were consistent with a scenario where the transport of sedimentary components from the trench slope to hadal depths is frequent, which has indeed been commonly shown by sediment observations at trench axes of the Izu-Ogasawara, Mariana, Japan, and Tonga trenches (Nozaki and Ohta, 1993; Glud et al., 2013; Oguri et al., 2013; Wenzhöfer et al., 2016) and supported by numerical modeling (Ichino et al., 2015).
In addition to the geochemical studies outlined above, $\sim 30$ vertical seawater samples, including 7 hadal samples, were collected mainly for biological analyses by the remotely operated vehicle $A B I S M O$ at the Challenger Deep in the southern MT. Phylogenetic analyses from these samples revealed a hadal-water-specific microbial community, named the hadal biosphere, which has been shown to be distinct from the abyssal one (Nunoura et al., 2015). Mechanisms developing the hadal biosphere are considered to be likely associated with the lateral supply of sedimentary organic matter from the trench slope and the subsequent activation of the microbial community including ammonia and nitrite oxidizers.

Despite these efforts, the spatial coverage within and among trenches, as well as the comprehensiveness of the (bio)geochemical dataset, is still greatly limited compared to other parts of the ocean. To resolve these problems and to obtain data from hadal depths in a directly comparable quality to the global CTD-CMS observations, the development of a full-depth CTD-CMS system is needed and indeed has long been awaited. Ultimately, a full-depth-rated CTD-CMS system was equipped on the research vessel R/V Kaimei, launched in 2015. From 2016, the R/V Kaimei CTD-CMS system has been deployed at the IOT and the MT including for five full-depth vertical sequences at trench axes. Here we report the results of (bio)geochemical analyses for these CTD-CMS-collected seawater samples, including a total of 57 samples from hadal depths, mostly in the IOT. Tracers for the lateral supply of sedimentary organic matter (methane, manganese, and total organic carbon) and microbial nitrogen metabolisms (nitrate, ammonium, and nitrous oxide) as well as general oceanographic parameters were analyzed.

\section{Settings and methods}

\subsection{Study area and equipment}

The seawater column of the IOT and the MT were investigated during three R/V Kaimei cruises (KM16-02, KM1608, and KM17-01) and a R/V Shinsei-maru cruise (KS-16-8). Locations of the sampling stations are shown in Table 1 and Fig. 1. Although the term "hadal" generally refers to the zone below $6500 \mathrm{~m}$ (Jamieson, 2015), in this study we use hadal for depths below $7000 \mathrm{~m}$ and "abyssal" for depths between 4000 and $7000 \mathrm{~m}$, based on the vertical hydrographic constitution revealed by our observations (see Sect. 3.1). Seawater sampling was generally conducted at $50-250 \mathrm{~m}$ vertical intervals at each station.

$\mathrm{R} / \mathrm{V}$ Kaimei has a $12000 \mathrm{~m}$ long synthetic-fiber coaxial cable for the operation of its full-depth CTD-CMS system, which consists of a CTD sensor (SBE911plus; $11000 \mathrm{~m}$ rated), a carousel water sampler (SBE32; $11000 \mathrm{~m}$ rated) for 36 Niskin-X bottles, and a dissolved oxygen sensor (RINKO; $7000 \mathrm{~m}$ rated but tolerates $10000 \mathrm{~m}$ ). The CTD thermometer 
Table 1. Summary of stations.

\begin{tabular}{llllrrrrr}
\hline Cruise & Station & YYYYMMDD & Lat degree & Lat minute & Long degree & Long minute & Depth (m) & $* *$ Relative location \\
\hline KM16-02 & 31N01 & 20160505 & 31 & 18.2 & 141 & 46.7 & 5801 & WW \\
KM16-02 & 31 N03 & 20160506 & 31 & 20.0 & 142 & 14.5 & 9382 & A \\
KM16-02 & 31 N02 & 20160507 & 31 & 18.3 & 142 & 0.3 & 7093 & W \\
KM16-02 & 31 N04 & 20160507 & 31 & 19.1 & 142 & 38.9 & 6928 & E \\
KM16-02 & 31 N05 & 20160507 & 31 & 19.8 & 143 & 0.1 & 6162 & EE \\
KS-16-8 & 30N01 & 20160708 & 30 & 0.0 & 142 & 36.3 & 9190 & A \\
KS-16-8 & 32N01 & 20160711 & 32 & 9.0 & 142 & 0.0 & 7931 & W \\
KS-16-8 & 32N02 (KEO) & 20160706 & 32 & 21.6 & 144 & 24.2 & 5737 & EE \\
KM16-08 & 34N03 & 20160913 & 34 & 57.6 & 142 & 33.5 & 5837 & E \\
KM16-08 & 34N02 & 20160914 & 34 & 0.1 & 141 & 57.2 & 9224 & A \\
KM17-01 & 29N02 & 20170106 & 29 & 17.6 & 143 & 30.8 & 6062 & E \\
KM17-01 & 29N01 & 20170107 & 20 & 8.9 & 142 & 48.9 & 9820 & A \\
KM17-01 & 26N01 & 20170108 & 26 & 10.3 & 143 & 15.2 & 3306 & $($ A) \\
KM17-01 & 27N01 & 20170108 & 27 & 30.1 & 143 & 19.1 & 8949 & A \\
KM17-01 & 24N01 & 20170109 & 24 & 16.4 & 143 & 38.3 & 8798 & A \\
KM17-01 & 24N02 & 20170109 & 24 & 15.5 & 144 & 15.0 & 4898 & E \\
KH-84-3 & AN1* & $19840823-30$ & 29 & & & & & \\
KH-94-3 & LM2* & $19941004-06$ & 29 & 5.0 & 142 & 51.0 & 9768 & A \\
\hline
\end{tabular}

* Gamo and Shitashima (2018). ** Relative locations on the trench axis: WW: far west; W: west; A: Axis; E: east; EE: far east.
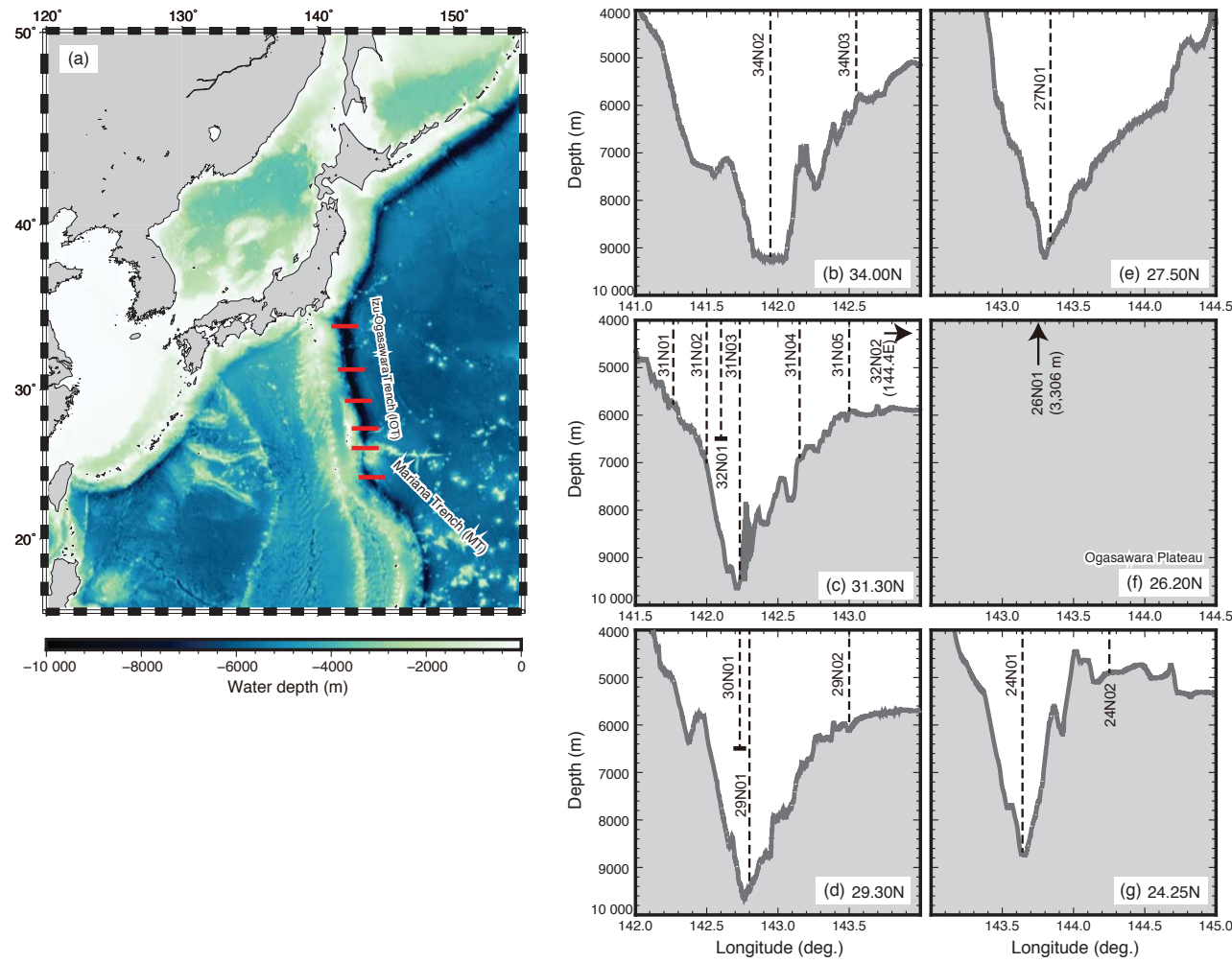

Figure 1. Seafloor topography of (a) the western North Pacific and (b-g) a cross section of the inner trench. Horizontal red lines in panel (a) represent the sections shown in panels $(\mathbf{b}-\mathbf{g})$. Vertical dashed lines in panels $(\mathbf{b}-\mathbf{g})$ represent CTD-CMS stations (see Table 1).

(SBE3plus) was calibrated in situ with a deep ocean standard thermometer (SBE35; $7000 \mathrm{~m}$ rated) to correct a pressure dependency of the CTD thermometer (Uchida et al., 2015). The full dataset of the CTD observations will be deposited on a website and discussed elsewhere (Uchida et al., 2018). R/V Shinsei-maru has an $8000 \mathrm{~m}$ long steel coaxial cable for the operation of its CTD-CMS system (6500 m rated), consisting of a CTD sensor (SBE911plus), a carousel water sampler 
(SBE32), 24 Niskin-X bottles, and a dissolved oxygen sensor (SBE43).

\subsection{Analyses}

The potential density anomaly $\left(\sigma_{6 \mathrm{~K}}\right.$ : pref $=6000 \mathrm{dbar}$; potential density minus $1000 \mathrm{~kg} \mathrm{~m}^{-3}$ ) was calculated from the CTD dataset using the TEOS-10 software, calibrated using the practical salinity measured. Dissolved oxygen was also measured on the ship using a modified Winkler's titration method (Dickson, 1996). Automatic photometric titrators (DOT-01X or DOT-15X, Kimoto Electronic Co. Ltd., Osaka, Japan) and automatic burettes (APB-410, APB-510, and/or APB-610, Kyoto Electronic Manufacturing Co. Ltd., Tokyo, Japan) for sodium thiosulfate and potassium iodate were used. A precision estimated from the standard deviation of replicate measurements was within $0.2 \mu \mathrm{mol} \mathrm{kg}-1$.

Nitrate+nitrite (hereafter, nitrate), phosphate, and silicate concentrations were determined using AutoAnalyzerII (for nitrate and nitrite; Technicon, Dublin, Ireland) and TrAACS 800 (for silicate and phosphate; Bran+Luebbe, Norderstedt, Germany) in Japan Sea National Fisheries Research Institute (Hydes et al., 2010; Kodama et al., 2015). Nutrient samples were frozen in a deep freezer at $-80^{\circ} \mathrm{C}$ immediately after subsampling onboard and stored below $-20^{\circ} \mathrm{C}$ until measurements were taken. Another set of samples was collected during the KM16-08 cruise just for silicate analysis, and this was stored at $4{ }^{\circ} \mathrm{C}$ in the dark and analyzed within 2 weeks of sampling. In-house standards, prepared using artificial seawater, were used in combination with commercially available nutrient standard solutions (RMNS, KANSO Technos, Tsukuba, Japan) (Aoyama et al., 2012), but only RMNS was used for the standardization of concentrations. RMNS lots of batches BD, BZ, and BS were used for samples taken during the cruise KM16-02, while batches BT, BS, and CB were used for KM16-08 and batches BY, CA, and CB for KM1701. Phosphate and silicate data could not be obtained for samples taken during KM17-01 due issues with the instrument. The determination limits of nutrient concentrations, defined as tripled standard deviations of blank values, were $<0.1,<0.05$, and $<1 \mu \mathrm{mol} \mathrm{kg}{ }^{-1}$ for nitrate, phosphate, and silicate, respectively. Analytical errors in our measurement systems, estimated by repeated analyses $(n=5)$ using the BV batch lot of RMNS, were $0.48,0.04$, and $0.21 \mu \mathrm{mol} \mathrm{kg}-1$ for nitrate, phosphate, and silicate, respectively, as previously reported in the inter-laboratory comparisons of seawater nutrient concentrations (see Aoyama et al., 2016). Seawater for ammonium analysis was subsampled into a $25 \mathrm{~mL}$ polypropylene bottle after being triple-rinsed with seawater, and ammonium concentration was measured onboard using a fluorometric (OPA - o-phthaldialdehyde) method (Holmes et al., 1999). The detection limit and analytical precision of ammonium concentrations were as low as 10 and $\pm 5 \mathrm{nM}$ (when concentrations was $<100 \mathrm{nM}$ ), respectively.
Nitrogen and oxygen isotopic compositions of nitrate (and nitrate+nitrite) were analyzed by the denitrification method (Casciotti et al., 2002; Mcllvin and Casciotti, 2011) at the Japan Agency for Marine-Earth Science and Technology (JAMSTEC). A subsample $(\sim 50 \mathrm{~mL})$ of seawater was filtered onboard with a $0.45 \mu \mathrm{m}$ cellulose acetate membrane filer (ADVANTEC) and stored at $-20^{\circ} \mathrm{C}$. For surface seawater $(<500 \mathrm{~m})$ in which nitrite was detected significantly at the AutoAnalyzer (AA) analysis, sulfamic acid was injected to sample seawater to eliminate nitrite as NO volatile (Granger and Sigman, 2009) while the samples without the acid injection were also analyzed. The isotopic compositions of nitrate+nitrite (without the acid processing) and nitrate (with the acid processing) are annotated by subscripts of $\mathrm{N}+\mathrm{N}$ and $\mathrm{NO}_{3}$, respectively. The seawater samples were then injected into a laboratory denitrification culture in $20 \mathrm{~mL}$ headspace glass vials. Nitrate (and nitrite) was quantitatively converted to nitrous oxide using the strain Pseudomonas chlororaphis (JCM20509 = ATCC13985), a denitrifying bacterium lacking the ability to reduce $\mathrm{N}_{2} \mathrm{O}$. International reference materials (IAEA-N3, USGS-32, and USGS-34 for both $\delta^{15} \mathrm{~N}_{\mathrm{NO}_{3}}$ and $\delta^{18} \mathrm{O}_{\mathrm{NO}_{3}}$, and USGS-35 for $\delta^{18} \mathrm{O}_{\mathrm{NO}_{3}}$; Böhlke et al., 2003) and in-house working standard were included within a batch of 120 bottles for a series of analysis. The $\mathrm{N}_{2} \mathrm{O}$ produced by each culture was then analyzed using a ThermoFinnigan GasBench+PreCon trace gas concentration system, interfaced to a Delta V Plus isotope-ratio mass spectrometer. The conversion efficiency from nitrate to $\mathrm{N}_{2} \mathrm{O}$, evaluated by comparing with the TrAACS 800 analysis, was above $95 \%$ in this study. Analytical precisions were estimated to be within $0.2 \%$ for $\delta^{15} \mathrm{~N}$ and $0.3 \%$ for $\delta^{18} \mathrm{O}$. The isotopic compositions of surface seawaters containing significant nitrite were different between the acid-treated and non-treated samples (Supplement Table S1) and should be interpreted with caution (e.g., Casciotti and McIlvin, 2007; Kemeny et al., 2016).

The potential nitrification activity was estimated during the KM16-08, KM17-01, and KS-16-8 cruises by ship-based incubation of seawater with three ${ }^{15} \mathrm{~N}$-labeled substrates (ammonium, urea, and glutamine) according to an established method (e.g., Shiozaki et al., 2016). Deep-sea water samples were subsampled into $125 \mathrm{~mL}$ pre-combusted glass vials. Each of ${ }^{15} \mathrm{~N}$-ammonium, ${ }^{15} \mathrm{~N}$-urea, and ${ }^{15} \mathrm{~N}$-glutamine (amide group labeled) were then spiked into the vials to give a final concentration of $50 \mathrm{nM}$, and the samples were incubated at $4{ }^{\circ} \mathrm{C}$ in the dark for $5-10$ days prior to filtration $(0.45 \mu \mathrm{m}$ cellulose acetate membrane filer; ADVANTEC). The nitrogen isotopic ratio of the nitrate+nitrite within the filtrate was measured according to same method as for native nitrate analyses, as described above. For comparative purposes, seawater from shallower than $1000 \mathrm{~m}$ was also examined by a similar method, with incubation being carried out under in situ temperatures and for a short duration of $\leq 12 \mathrm{~h}$. For the calculation of nitrification activity, it was assumed that the concentrations of ammonium, urea, and glutamine 
were negligible in the native deep-sea water. The detection limit of nitrification activity, determined based on significant changes in the nitrate isotope ratios ( $>0.6 \%$ o, 3 times higher than the analytical uncertainty) between ${ }^{15} \mathrm{~N}$-spiked and nonspiked seawaters after the incubation, was estimated to be $0.02 \mathrm{nmol} \mathrm{L}^{-1}$ day $^{-1}$.

The total organic carbon (TOC) concentration was determined using a total organic carbon analyzer (TOC-L, Shimadzu Co., Kyoto, Japan) following a published analytical method (Wakita et al., 2016), with some minor modifications. To determine the TOC, instead of dissolved organic carbon (Wakita et al., 2016), seawater samples were not filtrated on the ship. The TOC concentrations were calibrated using reference materials (provided by Dennis A. Hansell, Miami University) and determined with a precision of $\pm 1.0 \mu \mathrm{m}$. The radiocarbon content $\left(\Delta^{14} \mathrm{C}\right)$ of the dissolved inorganic carbon (DIC) was measured, following the methods published by Kumamoto et al. (2013), at the Institute of Accelerator Analysis Ltd in Shirakawa, Japan (using a Pelletron 9SDH2, National Electrostatics Corporation, USA) with a 4\%o analytical error.

Concentrations and isotopic compositions of nitrous oxide $\left(\mathrm{N}_{2} \mathrm{O}\right)$ and methane $\left(\mathrm{CH}_{4}\right)$ were determined according to published methods (Hirota et al., 2010) with some modifications for $\mathrm{CH}_{4}$ purification (Okumura et al., 2016a). Each seawater sample was introduced into a $120 \mathrm{~mL}$ glass vial from the Niskin bottle, sealed with a butyl rubber septum and aluminum cap after the addition of $0.2 \mathrm{~mL}$ mercury chloridesaturated solution for poisoning, and stored at $4{ }^{\circ} \mathrm{C}$ until the measurement. $\mathrm{N}_{2} \mathrm{O}$ and $\mathrm{CH}_{4}$ dissolved in the seawater were extracted and purified by purge-and-trap gas chromatography prior to the introduction into a MAT253 isotope-ratio mass spectrometer. Resistors of MAT253 Faraday cups for monitoring $\mathrm{m} / \mathrm{z}$ of 44,45 , and 46 for $\mathrm{CO}_{2}$ derived from $\mathrm{CH}_{4}$ oxidation were set, respectively, at $3 \times 10^{9}, 3 \times 10^{11}$, and $1 \times 10^{12} \Omega$, instead of the generally used $3 \times 10^{8}, 3 \times 10^{10}$, and $1 \times 10^{11} \Omega$. This modification improved the detection limit of $\mathrm{CH}_{4}$ to as low as $0.08 \mathrm{nmol} \mathrm{L}^{-1}$, while keeping the comparable analytical precision. Errors for analyses conducted during the present study were estimated from repeated analyses of a sample and were $10 \%$ for $\mathrm{N}_{2} \mathrm{O}$ concentration, $0.2 \%$ for $\delta^{15} \mathrm{~N}_{\mathrm{N}_{2} \mathrm{O}}, 0.5 \%$ o for $\delta^{18} \mathrm{O}_{\mathrm{N}_{2} \mathrm{O}}, 20 \%$ for $\mathrm{CH}_{4}$ concentration, and $0.3 \%$ oror $\delta^{13} \mathrm{C}_{\mathrm{CH}_{4}}$.

The manganese concentration was measured at an onshore laboratory by the luminol- $\mathrm{H}_{2} \mathrm{O}_{2}$ chemiluminescence detection method (Ishibashi et al., 1997). For Mn analysis, $100 \mathrm{~mL}$ of seawater was drawn from a Niskin bottle to a plastic bottle. As $0.5 \mathrm{~mL}$ of ultrapure nitric acid (Tamapure AA-10, Tama Chemical) was added into the sample without filtration, the concentration reported in this study is total dissolvable fraction (e.g., Gamo and Shitashima, 2018). The samplings were conducted during the KM16-08 and KM1701 cruises. The Mn concentrations were determined within $5 \%$ analytical errors and calibrated by simultaneous analy- sis of an international standard NASS-5 (given concentration $16.7 \pm 1.04 \mathrm{nM})$.

To examine the validity of our sampling and analyses, nutrients concentrations of abyssal waters at neighbor stations obtained by the WOCE reoccupation program (Stn. 65-90 on P10 line and Stn. 273-321 on P03 revisit line) were selected (Kawano and Uchida, 2007a, b). The basin-scale $\Delta^{14} \mathrm{C}-\mathrm{DO}$ (dissolved oxygen) relation below $4000 \mathrm{dbar}$ from stations of the WOCE P01 (Kawano et al., 2009) and P03 (Kawano and Uchida, 2007a) was also used for interpretation in addition to P02 (https://cchdo.ucsd.edu/cruise/318M200406, last access: June 2018).

All analytical results, full-depth vertical profiles, and the overall summary of hadal water analyses are presented in Supplement Table S1, Fig. S1, and Table 2, respectively. As the present study focuses on observations and data from deep waters, properties of the surface water are generally used for validating the observations and only discussed minimally.

\section{Results}

\subsection{Major hydrographic property}

Vertical profiles of the potential density anomaly $\left(\sigma_{6 \mathrm{~K}}\right)$ revealed that a dense, well-mixed water mass occupies the deeper parts of the trenches (Fig. 2a). The boundary between this well-mixed layer and the abyssal layer above is seen as a change in $\sigma_{6 \mathrm{~K}} 3$ times greater than a standard deviation within the nearly constant density of the well-mixed layer. This boundary was shallower than $7000 \mathrm{~m}$ in all axis stations (Fig. 2a). We therefore redefine hadal waters as being deeper than $7000 \mathrm{~m}$ in this study although 6000 or $6500 \mathrm{~m}$ have been used in general (Jamieson et al., 2010; Walting et al., 2013).

Both potential density and DO of the hadal water at the MT station (54.356 and $172 \mu \mathrm{mol} \mathrm{kg}{ }^{-1}$ ) were higher than those at the IOT stations ( 54.350 and $164 \mu \mathrm{mol} \mathrm{kg}^{-1}$ ) (Fig. 2a and b). Such clear differences in properties between hadal waters within the two trenches are in line with the northward bottom current in the western Pacific (Wijffels et al., 1998) as well as the presence of a geographical barrier between IOT and MT (Ogasawara Plateau, Fig. 1). Detailed analyses of the CTD dataset, in addition to its comparison with past CTD observations (Taira et al., 2005; Taira, 2006; Gamo and Shitashima, 2018), will be presented elsewhere (Uchida et al., 2018).

\subsection{Nitrogen biogeochemistry (nitrate, $\mathrm{N}_{2} \mathrm{O}$, ammonium, and potential nitrification activity)}

Vertical profiles of nitrate concentrations agreed well among all stations (Fig. 2c). Nitrate concentrations of hadal and abyssal waters at IOT stations were almost constant at $35.20 \pm 0.41 \mu \mathrm{mol} \mathrm{kg}{ }^{-1}(n=47)$ and $35.50 \pm 0.68 \mu \mathrm{mol} \mathrm{kg}^{-1}$ $(n=149)$, respectively (Table 2$)$. The hadal and abyssal nitrate concentrations at the MT stations were $34.72 \pm$ 
Table 2. Summary of analyses. AVG: average.

\begin{tabular}{|c|c|c|c|c|c|c|c|c|c|c|c|c|}
\hline & & $\begin{array}{r}\text { DO } \\
\mu \mathrm{mol} \mathrm{kg}\end{array}$ & $\begin{array}{r}\text { Nitrate } \\
\mu \mathrm{mol} \mathrm{kg}{ }^{-1}\end{array}$ & $\begin{array}{r}\delta^{15} \mathrm{~N}_{\mathrm{N}+\mathrm{N}} \\
\% \circ\end{array}$ & $\begin{array}{r}\delta^{18} \mathrm{O}_{\mathrm{N}+\mathrm{N}} \\
\% \circ\end{array}$ & $\begin{array}{r}\mathrm{PO}_{4} \\
\mu \mathrm{mol} \mathrm{kg}\end{array}$ & $\begin{array}{r}\mathrm{SiO}_{2} \\
\mu \mathrm{mol} \mathrm{kg}{ }^{-1}\end{array}$ & $\begin{array}{r}\mathrm{N}_{2} \mathrm{O} \\
\mathrm{nM}\end{array}$ & $\begin{array}{r}\delta^{15} \mathrm{~N}_{\mathrm{N}_{2} \mathrm{O}} \\
\% \text { \% }\end{array}$ & $\begin{array}{r}\delta^{18} \mathrm{O}_{\mathrm{N}_{2} \mathrm{O}} \\
\% \text { \%o }\end{array}$ & $\begin{array}{r}\text { TOC } \\
\mathrm{uM}\end{array}$ & $\begin{array}{r}\Delta^{14} \mathrm{C} \\
\%\end{array}$ \\
\hline \multirow{3}{*}{$\begin{array}{l}\text { Izu-Ogasawara } \\
\text { (this study) }\end{array}$} & AVG & 164.0 & 35.2 & 5.10 & 2.23 & 2.46 & 145.6 & 17.7 & 8.82 & 51.56 & 37.9 & -206.6 \\
\hline & $\mathrm{SD}$ & 0.27 & 0.41 & 0.15 & 0.11 & 0.06 & 0.2 & 1.3 & 0.22 & 0.26 & 1.1 & 4.4 \\
\hline & $n$ & 47 & 47 & 25 & 25 & $23 *$ & $11 *$ & 47 & 47 & 47 & 45 & 40 \\
\hline \multirow{2}{*}{$\begin{array}{l}\text { Izu-Ogasawara } \\
(\text { G\&S2018**) }\end{array}$} & AVG & 165.7 & 35.1 & NA & NA & 2.39 & $\sim 142$ & NA & NA & NA & NA & NA \\
\hline & SD & 0.7 & 0.3 & & & 0.04 & & & & & & \\
\hline \multirow{3}{*}{$\begin{array}{l}\text { Mariana } \\
\text { (this study) }\end{array}$} & AVG & 171.7 & 34.7 & 5.13 & 2.24 & \multirow[t]{3}{*}{ NA } & \multirow[t]{3}{*}{ NA } & 17.1 & 8.70 & 51.11 & 37.6 & -197.0 \\
\hline & SD & 0.04 & 0.05 & 0.08 & 0.05 & & & 0.8 & 0.10 & 0.24 & 0.6 & 3.9 \\
\hline & $n$ & 10 & 10 & 7 & 7 & & & 10 & 10 & 10 & 10 & 10 \\
\hline
\end{tabular}

* Data available only from KM16-08 cruise. ** Gamo and Shitashima (2018).

NA: not available.

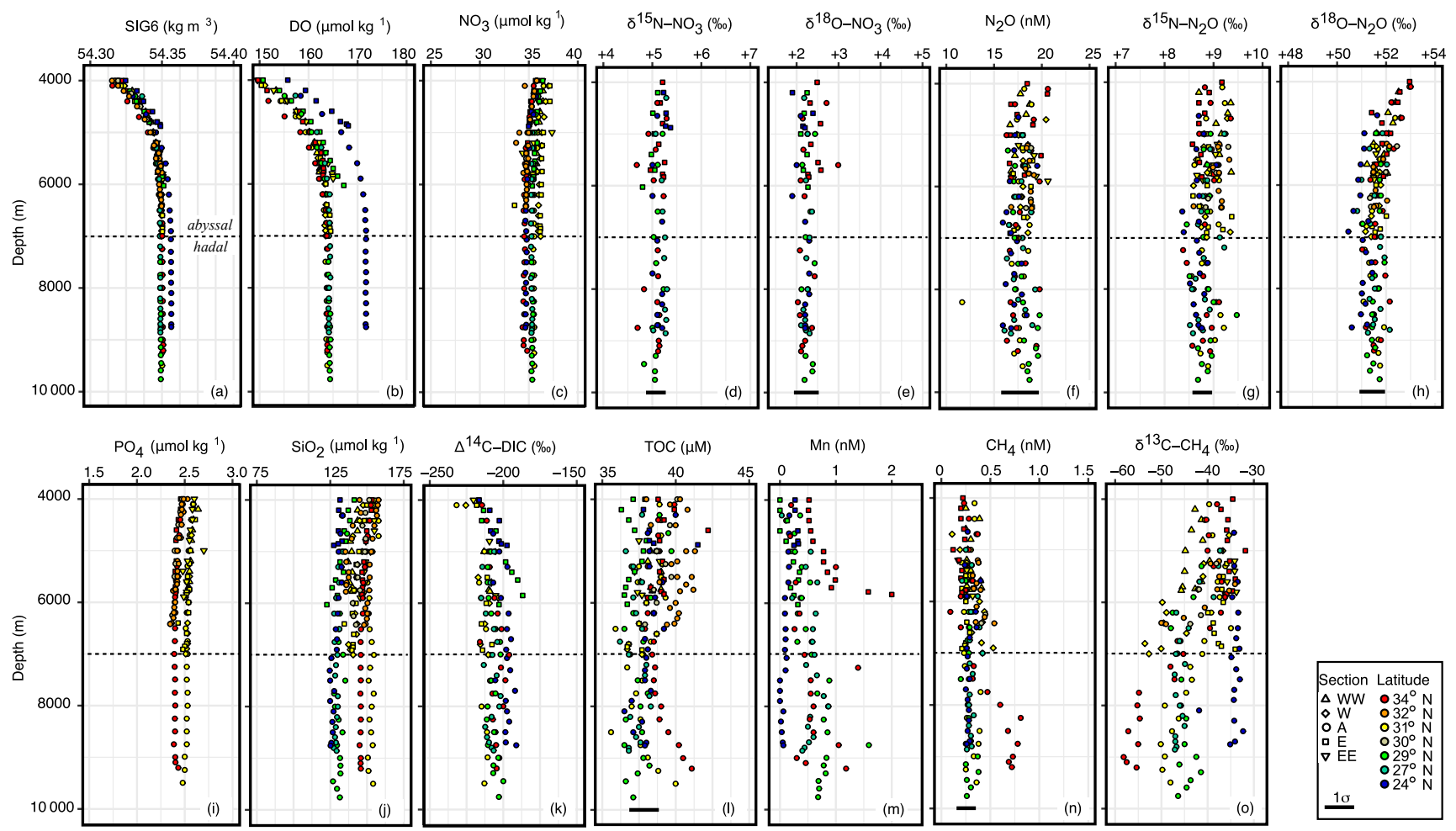

Figure 2. Vertical profiles of measured parameters. Symbol shapes and colors are classified by locations relative to the axis and latitude, respectively (see Table 1). Horizontal dashed lines indicate the abyssal-hadal boundary. Bold horizontal lines shown at the bottom of each panel represent $1 \sigma$ analytical errors, but this is not shown when the errors are smaller than the symbol size.

$0.05 \mu \mathrm{mol} \mathrm{kg}{ }^{-1}(n=10)$ and $35.12 \pm 0.38 \mu \mathrm{mol} \mathrm{kg}{ }^{-1}(n=$ 16), respectively. The nitrate variations in the hadal waters are smaller than the analytical error $\left(0.48 \mu \mathrm{mol} \mathrm{kg}^{-1}\right)$ while a greater nitrate variation in the IOT abyssal water likely reflects a vertical gradient within abyssal zone. Nitrate concentrations of the abyssal waters presented herein were found to be consistent with those at neighboring stations in WOCE $\mathrm{P} 03$ and P10 lines $\left(35.36 \pm 0.48 \mu \mathrm{mol} \mathrm{kg}^{-1} ; n=315\right)$, confirming accurate quantification. Furthermore, the hadal water value for the IOT agrees well with those observed at AN1 in 1984 (35.1 $\pm 0.3 \mu \mathrm{mol} \mathrm{kg}^{-1}$ ) (Gamo and Shitashima, 2018).
The $\delta^{15} \mathrm{~N}_{\mathrm{N}+\mathrm{N}}$ and $\delta^{18} \mathrm{O}_{\mathrm{N}+\mathrm{N}}$ values in the IOT (Fig. 2d, e) were also found to be constant through hadal and abyssal layers at $+5.10 \pm 0.15 \%$ and $+2.22 \pm 0.11 \%$ o $(n=25$, hadal $)$ and $+5.10 \pm 0.14 \% o$ and $+2.32 \pm 0.20 \%$ o $(n=28$, abyssal $)$, respectively (Fig. 2 and Table 2). Isotopic characteristics of the deep-sea water at the IOT region were consistent with the hadal water at the north MT (as reported herein), the Challenger Deep (Nunoura et al., 2015), and other published reports of deep-sea water from the Pacific (e.g., Casciotti, 2016). This isotopic consistency as well as the concentrations suggests little production/consumption of nitrate +nitrite in the IOT hadal water. For waters obtained above $500 \mathrm{~m}$ where 
nitrate concentrations were low $\left(<20 \mu \mathrm{mol} \mathrm{kg}^{-1}\right)$, the isotopic compositions varied between +3 and $+11 \% o\left(\delta^{15} \mathrm{~N}_{\mathrm{NO}_{3}}\right.$ and $\left.\delta^{15} \mathrm{~N}_{\mathrm{N}+\mathrm{N}}\right)$ and +1 and $+22 \% o\left(\delta^{18} \mathrm{O}_{\mathrm{NO}}\right.$ and $\left.\delta^{18} \mathrm{O}_{\mathrm{N}+\mathrm{N}}\right)$ (Table S1). The low $\delta^{15} \mathrm{~N}_{\mathrm{NO}_{3}}$ and $\delta^{18} \mathrm{O}_{\mathrm{NO}_{3}}$ values at the surface imply the contribution of nitrogen fixation whereas the high $\delta^{15} \mathrm{~N}_{\mathrm{NO}_{3}}$ and $\delta^{18} \mathrm{O}_{\mathrm{NO}_{3}}$ values could be caused by denitrification (e.g., Casciotti, 2016).

Identical vertical profiles were seen for both $\mathrm{N}_{2} \mathrm{O}$ concentrations and isotopic compositions, across all stations (Fig. 2f, g, h). $\mathrm{N}_{2} \mathrm{O}$ concentrations, $\delta^{15} \mathrm{~N}_{\mathrm{N}_{2} \mathrm{O}}$, and $\delta^{18} \mathrm{O}_{\mathrm{N}_{2} \mathrm{O}}$ in hadal and abyssal waters of the IOT were constant at $17.7 \pm 1.3 \mathrm{nM},+8.8 \pm 0.2 \%$ o, and $+51.6 \pm 0.3 \%$ o $(n=47$, hadal $)$ and $18.1 \pm 1.0 \mathrm{nM},+8.9 \pm 0.2 \% o,+51.8 \pm 0.4 \%$ o $(n=$ 99, abyssal), respectively (Fig. 2 and Table 2). These characteristics of deep-sea $\mathrm{N}_{2} \mathrm{O}$ in the IOT region are consistent with those in the MT (this study) and other stations in the North Pacific such as ALOHA (Popp et al., 2002) and KNOT (Toyoda et al., 2002). In turn, variable concentrations (5$42 \mathrm{nM})$ and isotopic composition $(+6.2-+9.5 \%$ and $+44-$ $+57 \%$ for $\delta^{15} \mathrm{~N}_{\mathrm{N}_{2} \mathrm{O}}$ and $\delta^{18} \mathrm{O}_{\mathrm{N}_{2} \mathrm{O}}$, respectively) were seen in $\mathrm{N}_{2} \mathrm{O}$ above $4000 \mathrm{~m}$ depth in the IOT region which were not identical with other deep-sea water in the Pacific (Toyoda et al., 2017).

Ammonium concentrations at the IOT were not detectable $(<10 \mathrm{nM})$ for both hadal and abyssal waters, while at the surface, they were as high as $30 \mathrm{nM}$. This is consistent with hadal waters from the Challenger Deep, which also had negligible ammonium concentration (Nunoura et al., 2015).

The potential nitrification activity of the hadal and abyssal waters in all samples analyzed for the present study was below the determination limit $\left(\delta^{15} \mathrm{~N}\right.$ increase smaller than $0.6 \%$ ). Even if the $\delta^{15} \mathrm{~N}$ increase observed $(<0.6 \%$ ) was significant, the nitrification activity should be not higher than $0.02 \mathrm{nmol} \mathrm{L}^{-1}$ day $^{-1}$ (Fig. 3 and Supplement Table S2). The nitrification activity of the surface water was up to $5 \mathrm{nmol} \mathrm{L}^{-1} \mathrm{day}^{-1}$ and comparable to that reported from other oligotrophic stations such as ALOHA and BATS (1$8 \mathrm{nmol} \mathrm{L}^{-1} \mathrm{day}^{-1}$ ) (Beman et al., 2011), which serves to confirm the validity of our data. At DO minimum depth $(\sim 1500 \mathrm{~m})$, several incubations exhibited detectable nitrification activity (Fig. 3). The low potential of nitrification in the deep-sea water $\left(<0.02 \mathrm{nmol} \mathrm{L}^{-1} \mathrm{day}^{-1}\right)$ and the estimated residence time of hadal water $(\sim 5$ years: Nozaki et al., 1998) are not inconsistent with the negligible changes in nitrate $\left(\sim 35 \mu \mathrm{mol} \mathrm{kg}^{-1}\right)$ and nitrous oxide $(\sim 18 \mathrm{nM})$.

\subsection{Phosphate, silicate, radiocarbon, TOC, and manganese}

Phosphate concentrations at each station were generally constant through hadal and abyssal depths (Fig. 2i). For example, samples from the KM16-08 cruise exhibited phosphate concentrations of $2.40 \pm 0.01 \mu \mathrm{mol} \mathrm{kg}{ }^{-1}$ for hadal waters $(n=11)$ and $2.42 \pm 0.02 \mu \mathrm{mol} \mathrm{kg}{ }^{-1}$ for abyssal waters $(n=21)$, demonstrating a lack of hadal-specific phosphate

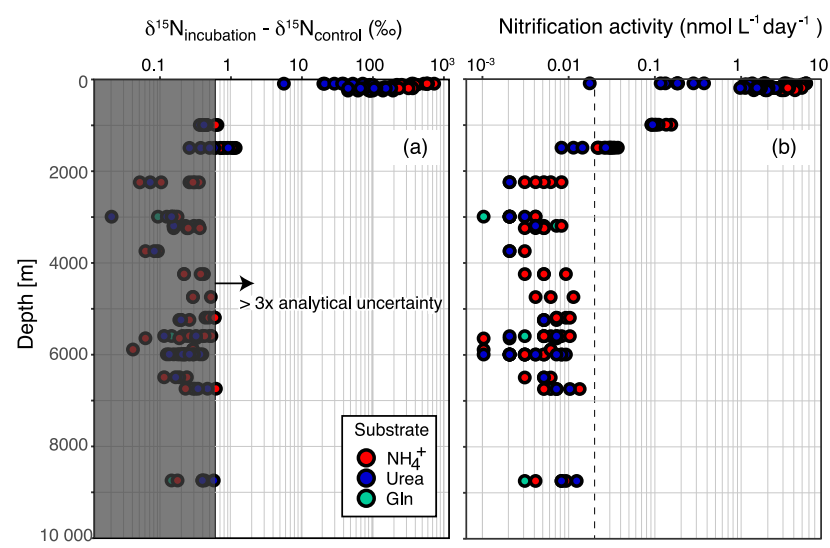

Figure 3. Vertical profiles of (a) $\delta^{15} \mathrm{~N}_{\mathrm{N}+\mathrm{N}}$ increase in cultivated batches from control batch after ${ }^{15} \mathrm{~N}$-spiked incubation and (b) nitrification activity calculated based on the $\delta^{15} \mathrm{~N}_{\mathrm{N}+\mathrm{N}}$ differences. Since a $\delta^{15} \mathrm{~N}_{\mathrm{N}+\mathrm{N}}$ increase 3 times greater than analytical uncertainty $(>0.6 \%)$ is regarded as significant, symbols in the grayshaded areas in panel (a) represent insignificant activity. Red, blue, and green symbols, respectively represent ${ }^{15} \mathrm{~N}$-labeled substrates of ammonium, urea, and glutamine. Horizontal axes are presented on a logarithmic scale.

cycle. Hadal phosphate concentrations during the KM16-08 cruise were consistent with those reported for hadal waters at AN1 in $1984\left(2.39 \pm 0.04 \mu \mathrm{mol} \mathrm{kg}^{-1}\right)$ (Gamo and Shitashima, 2018 ) and for abyssal water (below $5500 \mathrm{dbar}$ ) at neighboring stations of WOCE P03 and P10 $\left(2.44 \pm 0.02 \mu \mathrm{mol} \mathrm{kg}^{-1}\right.$, $n=77)$. A few systematic differences seemed present in phosphate concentrations among the different cruises (Fig. 2i) while the N-P relationships within each cruise were clearly linear (Supplement Table S1).

Silicate concentrations were highly variable (Fig. 2j). However, the variation was probably caused by freezing and thawing of the samples as discussed previously by Zhang and Ortner (1998). Compared to silicate distributions of the WOCE P03 and P10 lines, samples maintained at $4{ }^{\circ} \mathrm{C}$ from the KM16-08 cruise showed consistent vertical profiles, but the $-20^{\circ} \mathrm{C}$ frozen samples from the other cruises generally showed lower concentrations. At stations sampled during KM16-08 (34N02 and 34N03), silicate concentrations were constant within the hadal water $\left(145.6 \pm 0.2 \mu \mathrm{mol} \mathrm{kg}^{-1}\right.$, $n=11)$ but slightly variable in the abyssal water $(148.9 \pm$ $\left.2.3 \mu \mathrm{mol} \mathrm{kg}^{-1}, n=21\right)$ due to the presence of a vertical gradient. Concentrations measured from samples obtained at KM16-08 stations were consistent with those reported from LM2 ( 143 $\left.\mu \mathrm{mol} \mathrm{kg}^{-1}\right)$ (Gamo and Shitashima, 2018) but slightly higher than those of the abyssal water (below 5500 dbar) at neighboring stations of WOCE P03 and P10 (134.7 $\left.\pm 2.43 \mu \mathrm{mol} \mathrm{kg}{ }^{-1}, n=77\right)$.

The radiocarbon contents $\left(\Delta^{14} \mathrm{C}\right)$ of the hadal and abyssal waters at the IOT and the MT were constant within each water layer: $-206.6 \pm 4.4 \%$ ( $n=40$, IOT hadal $),-209.8 \pm$ $7.4 \%$ o $(n=62$, IOT abyssal $),-197.0 \pm 3.9 \%$ o $(n=10$, MT 


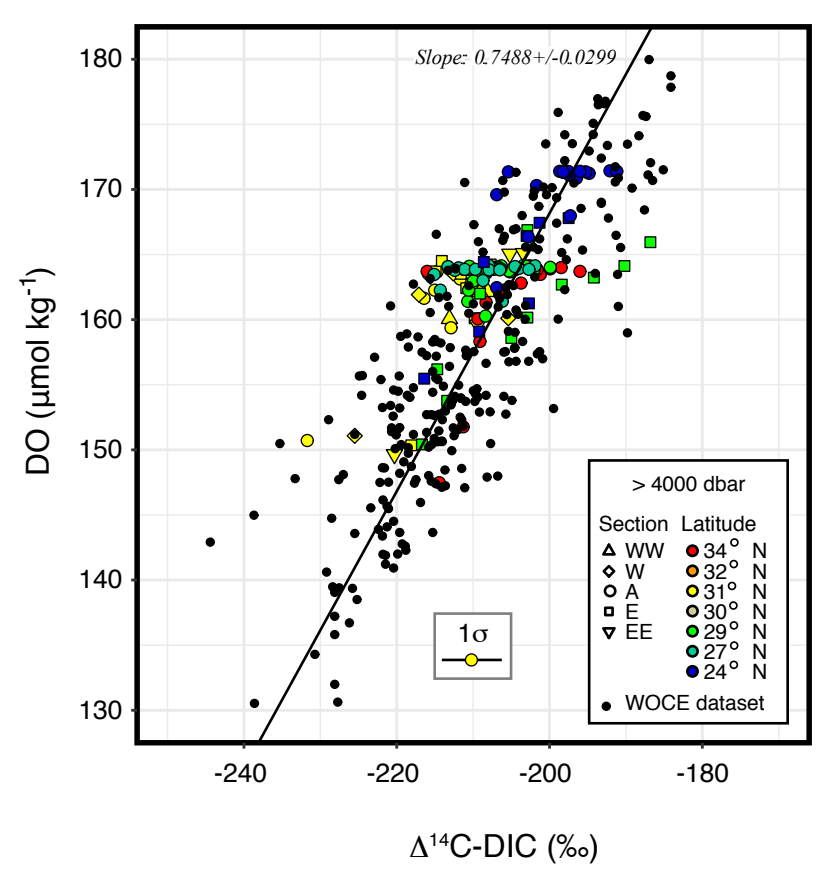

Figure 4. A DO- $\Delta^{14} \mathrm{C}$ plot for deep-sea water (> $\left.4000 \mathrm{dbar}\right)$. Colored symbols are the same as those in Fig. 2. Filled black circles and the diagonal line, respectively, represent a dataset from WOCE P01-P03 stations and its fitting line.

hadal), and $-210.0 \pm 5.8 \%$ ( $n=16$, MT abyssal) (Fig. $2 \mathrm{k}$ and Table 2). The variation in $\Delta^{14} \mathrm{C}$ for hadal depths, comparable to the analytical error $( \pm 4 \%$ ) , is reasonable because the change in $\Delta^{14} \mathrm{C}$ is expected to be $<1 \%$ from the estimated renewal time of $\sim 5$ years (Nozaki et al., 1998) and the $\Delta^{14} \mathrm{C}$-year relationship of $8.7 \mathrm{yr} \% o^{-1}$ (Sarmiento and Gruber, 2006). The DO $-\Delta^{14} \mathrm{C}$ relationships within the hadal water mass ranged within those of the Pacific deep-sea water from WOCE P01-P03 (Fig. 4). Variations in DO and $\Delta^{14} \mathrm{C}$ within the hadal water mass were too small to evaluate trench-specific oxygen consumption rates, but the DO- $\Delta^{14} \mathrm{C}$ relationship of the Pacific deep-sea water yields a slope of $0.749 \pm 0.030 \mu \mathrm{mol} \mathrm{kg}{ }^{-1} \% o^{-1}$, corresponding to an oxygen consumption rate of $0.0860 \pm 0.0034 \mu \mathrm{mol} \mathrm{kg} \mathrm{gr}^{-1} \mathrm{yr}^{-1}$.

The concentrations of TOC in the deep-sea water (below $2000 \mathrm{~m}$ ) of the IOT and MT regions were fairly constant at $\sim 38 \mu \mathrm{m}$ with the exception of a few samples (Fig. 21 and Table S2). This TOC level agrees well with DOC observations at a neighboring abyssal plain station $\left(\mathrm{S} 1: 30^{\circ} \mathrm{N}-145^{\circ} \mathrm{E}\right)$ (http://ebcrpa.jamstec.go.jp/k2s1/en/index.html, last access: June 2018). The TOC concentrations at the stations 34N02 and 31N03 appear to be increasing from 8000 and $9000 \mathrm{~m}$ towards the bottom, respectively, despite the well-mixed hydrographic property. The observed increases are significant beyond the analytical uncertainty of $\pm 1 \mu \mathrm{m}$ (Fig. 21). The hadal TOC gradient strongly suggests inner-trench TOC input since negligible TOC catabolism is expected from the negligible DO change $\left(<0.1 \mu \mathrm{mol}-\mathrm{O}_{2} \mathrm{~kg}^{-1}\right)$. Abyssal samples collected at $32^{\circ} \mathrm{N}$ during the KS-16-8 cruise also exhibited TOC concentrations higher than $40 \mu \mathrm{m}$.

Manganese concentrations of the hadal and abyssal waters at the IOT (except the 34N03 samples) and the MT were $0.71 \pm 0.27 \mathrm{nM}(n=35$, IOT hadal), $0.33 \pm 0.21 \mathrm{nM}$ ( $n=39$, IOT abyssal), $0.04 \pm 0.04 \mathrm{nM}(n=10$, MT hadal), and $0.19 \pm 0.09 \mathrm{nM}$ ( $n=16$, MT abyssal) (Fig. 2m). While the abyssal Mn concentrations were comparable between the IOT and MT, the hadal Mn concentrations were significantly higher at the IOT. Vertically, the Mn concentrations at the IOT and MT seemed higher and lower at the hadal depth, respectively. The hadal Mn ranges at the IOT were comparable between this study $(0.3-1.6 \mathrm{nM})$ and previous study $(0.6-$ $1.4 \mathrm{nM}$ ) (Gamo and Shitashima, 2018). The abyssal water at 34N03 showed an Mn increase toward the seafloor while an anomalously high background level of $\sim 0.5 \mathrm{nM}$ only at 34N03 implies the possibility of contamination during CTDCMS.

\subsection{Methane}

Methane concentrations were generally as low as $0.25 \mathrm{nM}$ below $2000 \mathrm{~m}$ deep (Fig. 2n). $\mathrm{CH}_{4}$ concentrations as low as $0.25 \mathrm{nM}$ are ubiquitous in deep-sea water (Hirota et al., 2010; Son et al., 2014) and are probably regulated by a minimum threshold in microbial uptake for aerobic methanotrophy. Counter to the general trend, an increase in methane concentrations to 3 times higher than the general level was detected in waters below $8000 \mathrm{~m}$ at the station 34N02 (Fig. 2n), despite well-mixed hydrographic properties.

$\delta^{13} \mathrm{C}$ values of $\mathrm{CH}_{4}$ were highly variable between -60 and $-30 \%$ (Fig. 20), despite there being little variation in concentrations among the sites (Fig. 2n). A clear spatial trend in $\delta^{13} \mathrm{C}_{\mathrm{CH}_{4}}$ values was observed in the IOT region (Fig. 5). Vertically, $\delta^{13} \mathrm{C}_{\mathrm{CH}_{4}}$ values were $\sim-38 \%$ o between 4000 and $6000 \mathrm{~m}$ and then generally decreased with increasing depth, and became constant below $8000 \mathrm{~m}$ (Fig. 2o). Below $8000 \mathrm{~m}$, $\delta^{13} \mathrm{C}_{\mathrm{CH}_{4}}$ values exhibited a north-south trend where the values were lower $(-56.2 \pm 1.4 \%: n=7)$ at $34^{\circ} \mathrm{N}$ than the other IOT stations $(-46.3 \pm 2.2 \%: n=23)$ and also the MT stations ( $-35.5 \pm 3.7 \%$ : $n=54)$ (Figs. 2o and 5). Moreover, values measured from abyssal waters suggested a west-east trend, with $\delta^{13} \mathrm{C}_{\mathrm{CH}_{4}}$ from the western stations (relative to the axis: Fig. 1) being generally lower than $-40 \%$ and from the eastern stations generally higher than $-40 \%$ o (Fig. 5).

\section{Discussion}

\subsection{Sedimentary compound release through sediment re-suspension at slopes}

Despite the well-mixed hydrographic properties, the $\mathrm{CH}_{4}$ heterogeneity in the IOT hadal water strongly suggests the occurrence of local $\mathrm{CH}_{4}$ source(s) within the trench, in addi- 

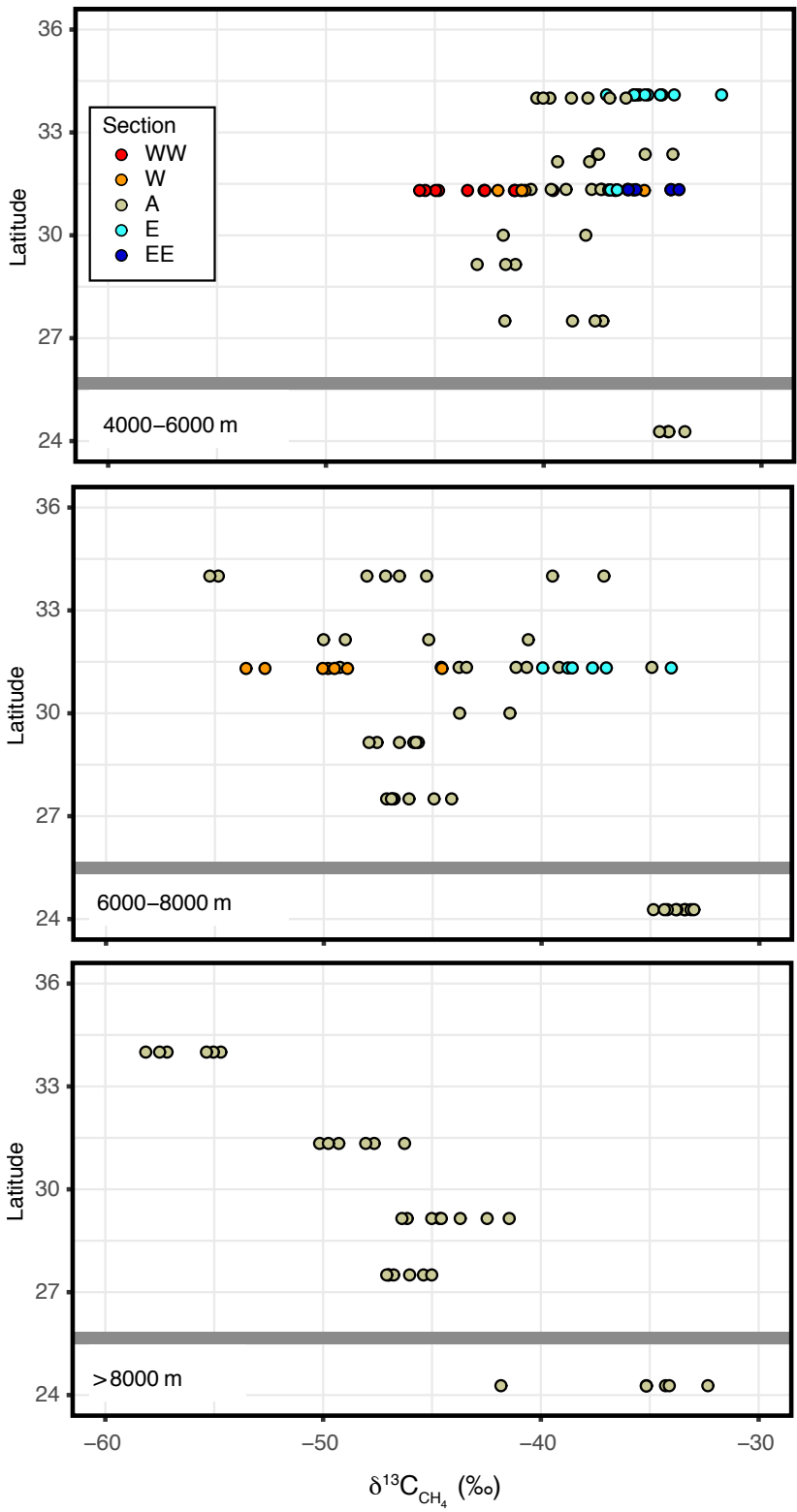

Figure 5. Spatial distribution of $\delta^{13} \mathrm{C}_{\mathrm{CH}_{4}}$ values. Symbols are classified by color according to relative locations on the trench axis. Long horizontal bars indicate the boundary between the IzuOgasawara and Mariana trenches: the Ogasawara Plateau.

tion to the deep Pacific seawater-sourced background $\mathrm{CH}_{4}$. The background $\mathrm{CH}_{4}$ has a concentration of $\sim 0.25 \mathrm{nM}$ with $\delta^{13} \mathrm{C}_{\mathrm{CH}_{4}}$ of $-38 \%$, while the $\mathrm{CH}_{4}$ from the local source would have $\delta^{13} \mathrm{C}_{\mathrm{CH}_{4}}$ of $\sim-58 \%$, as observed in the $34^{\circ} \mathrm{N}$ hadal water. The moderate $\delta^{13} \mathrm{C}_{\mathrm{CH}_{4}}$ value observed in the hadal waters from 27 to $32^{\circ} \mathrm{N}$ can be attributed to the kinetic isotope effect of microbial methane consumption, which causes ${ }^{13} \mathrm{C}$ enrichment in the remnant $\mathrm{CH}_{4}$ (Tsunogai et al., 2000; Feisthauer et al., 2011), in addition to water mass mixing (Fig. 6). Assuming that the end-member com-

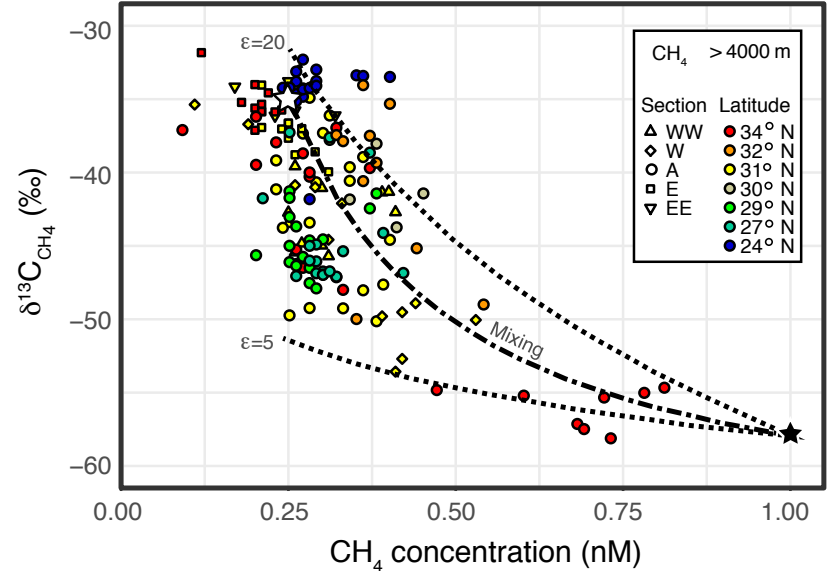

Figure 6. A plot between $\mathrm{CH}_{4}$ concentration and $\delta^{13} \mathrm{C}_{\mathrm{CH}_{4}}$. Colored symbols are same as those in Fig. 2. Open and filled stars, respectively, represent end-member values assumed for background seawater and inner-trench $\mathrm{CH}_{4}$ sources. Dashed curves represent theoretical isotope behaviors from the local $\mathrm{CH}_{4}$ source when kinetic isotope effects on microbial methanotrophy $(\varepsilon)$ are 5 and 20. A dash-dotted curve represents a bimodal mixing between two endmembers.

position of the local $\mathrm{CH}_{4}$ source within the trench is $1.0 \mathrm{nM}$ with $\delta^{13} \mathrm{C}_{\mathrm{CH}_{4}}$ of $-58 \%$ and taking the probable range of kinetic isotope effects $(\varepsilon=5-20 \%$ o) (Tsunogai et al., 2000; Feisthauer et al., 2011) into consideration, the compositional and isotopic variation in $\mathrm{CH}_{4}$ observed in the IOT can be reasonably explained (Fig. 6). The microbial consumption of $\mathrm{CH}_{4}$ in sub-nanomolar quantities, if it occurs, is not in conflict with the negligible change in DO observed, the detection limit of which is $\sim 100 \mathrm{nmol} \mathrm{kg}^{-1}$. This is also the case for the negligible change in $\Delta^{14} \mathrm{C}$ because the DIC concentration $(\sim 2.3 \mathrm{mM})$ was $6-7$ orders of magnitude higher than the $\mathrm{CH}_{4}$ concentration. Multiple $\mathrm{CH}_{4}$ local sources with different ${ }^{13} \mathrm{C}$ signatures, other than the $34^{\circ} \mathrm{N}$ source proposed above, are also a possibility in generating the $\delta^{13} \mathrm{C}_{\mathrm{CH}_{4}}$ variations observed within the IOT hadal water and do not conflict with the discussion above.

The observed ${ }^{13} \mathrm{C}$-depleted $\mathrm{CH}_{4}$ at the northern and western stations appears to be consistent with the two known bottom water currents. In addition to a generally northwardflowing basin-scale bottom current, a local counterclockwise current at $\sim 6000 \mathrm{~m}$ deep in the IOT was revealed by previous current meters deployment on the seafloor at $34^{\circ} \mathrm{N}$ (Fujio et al., 2000). The basin-scale current brings the background $\mathrm{CH}_{4}$ into the eastern sill of the IOT. On the other hand, the local counterclockwise current, particularly the southward current along with western slope, distributes the ${ }^{13} \mathrm{C}$ depleted $\mathrm{CH}_{4}$-rich water occurring at $34^{\circ} \mathrm{N}$ to the western part of the inner-trench water, resulting in $\delta^{13} \mathrm{C}_{\mathrm{CH}_{4}}$ values being lower on the western side of the $31^{\circ} \mathrm{N}$ line. Also, the north-south trend in $\delta^{13} \mathrm{C}_{\mathrm{CH}_{4}}$ below $8000 \mathrm{~m}$ mentioned above can be explained by a north-south mixing between the 
local ${ }^{13} \mathrm{C}$-depleted $\mathrm{CH}_{4}$ at $34^{\circ} \mathrm{N}$ and the background $\mathrm{CH}_{4}$ from the Ogasawara Plateau region. Nevertheless, multiple $\mathrm{CH}_{4}$ sources in addition to the proposed $34^{\circ} \mathrm{N}$ source can also generate the observed spatial heterogeneity in $\delta^{13} \mathrm{C}_{\mathrm{CH}_{4}}$ values.

Several local $\mathrm{CH}_{4}$ sources are known in the deep sea, but most of these are unlikely to be responsible for the hadal $\mathrm{CH}_{4}$ and other geochemical anomalies seen in the IOT, such as TOC, Mn, and ${ }^{222} \mathrm{Rn}$ (Gamo and Shitashima, 2018). Firstly, the discharge of high-temperature hydrothermal fluid is a well-known source for deep-sea $\mathrm{CH}_{4}$ plumes that are accompanied by $\mathrm{Mn}, \mathrm{Fe}$, and ${ }^{222} \mathrm{Rn}$ (e.g., Kadko et al., 1990; Resing et al., 2015). However, hydrothermal vents in the Izu-Ogasawara region are only expected to occur at the volcanic arc and back arc with depths of $\sim 1500 \mathrm{~m}$ (e.g., Tsunogai et al., 1994). Secondly, cold fluid seepage at accretionary prisms contains abundant $\mathrm{CH}_{4}$ (e.g., Toki et al., 2004), but it is unlikely to occur at the IOT, which is nonaccretionary. Thirdly, serpentinization-associated $\mathrm{CH}_{4}$-rich geofluids have been reported from seafloors where (sea)water penetrates into peridotite (Fryer, 2012; Kelley et al., 2005). An example has been reported from the terrestrial-ward slope of the Challenger Deep, southern MT (Okumura et al., 2016b). The exposure of serpentinized peridotite below $5500 \mathrm{~m}$ at the terrestrial-ward slope of the IOT (Morishita et al., 2011; Harigane et al., 2013) indicates that discharge of $\mathrm{CH}_{4}$-rich geofluids occurring in the IOT cannot be ruled out, but such geofluid systems have never been discovered before. Seafloor serpentinization geofluids reported so far exhibit $\delta^{13} \mathrm{C}_{\mathrm{CH}_{4}}$ values higher than $-40 \%$ (Konn et al., 2015) and are not compatible with the hadal $\mathrm{CH}_{4}$ anomaly observed in this study. Also, it appears unlikely for highly alkaline serpentinization-based geofluids to generate $\mathrm{Mn}$ and Fe plumes. In addition to the fluid releases, in situ microbial methanogenesis in the deep-sea water column, which could generate ${ }^{13} \mathrm{C}$-depleted $\mathrm{CH}_{4}$ if it does occur (e.g., Okumura et al., 2016a), is also very unlikely due to high DO levels through the water column in the IOT (e.g., Reeburgh, 2007).

Sedimentary compounds released into the water column, through sediment re-suspension, are therefore the most likely process responsible for generating the $\mathrm{CH}_{4}$ (and TOC) anomaly in the IOT water mass, as previously proposed for other hadal-specific geochemical anomalies of $\mathrm{Mn}$ and ${ }^{222} \mathrm{Rn}$ (Gamo and Shitashima, 2018) and microbiological characteristics (Nunoura et al., 2015). Earthquake-induced sediment re-suspension and the associated increase in turbidity as well as anomalies in $\mathrm{CH}_{4}$ and $\mathrm{Mn}$ have been occasionally reported in the deep-sea water column (Tsunogai et al., 1998; Gamo et al., 2007; Kawagucci et al., 2012). Values of $\delta^{13} \mathrm{C}_{\mathrm{CH}_{4}}$ ranging from -80 to $-60 \%$ o were observed in the turbid seawater (Kawagucci et al., 2012) and the shallow part of seafloor sediment (Ijiri et al., 2009; Heuer et al., 2009), compatible with that of the hadal water at the $34^{\circ} \mathrm{N}$ stations. The $\mathrm{CH}_{4}$ released is attributable to both $\mathrm{CH}_{4}$ dissolved in porewater and
$\mathrm{CH}_{4}$ adsorbed on the sediment surface although they cannot be distinguished by water column observation. Also, the increase in TOC observed is attributable to both suspended organic particles directly entrained into the Niskin bottles and the dissolved organic matter stripped from the suspended particles (Komada and Reimers, 2001). Alternatively, the small changes in $\delta^{13} \mathrm{C}_{\mathrm{CH}_{4}}, \mathrm{Mn}$, and TOC through hadal and abyssal waters at the $24^{\circ} \mathrm{N}$ stations suggest little input of sedimentary compounds at the north end of the MT.

An explanation for a vertical layer $\sim 2000 \mathrm{~m}$ in thickness exhibiting anomalously high $\mathrm{CH}_{4}$ (this study) and ${ }^{222} \mathrm{Rn}$ (Gamo and Shitashima, 2018) requires sedimentary compounds to be released not only from the axis bottom but also from the trench slopes. Re-suspensions from the trench slope have been commonly suggested by sediment observations that identified the rapid accumulation of the axis sediment, in association with frequent sediment transports from slopes (Nozaki and Ohta, 1993; Glud et al., 2013; Oguri et al., 2013; Luo et al., 2018). As earthquake-induced turbid seawater was indeed evident over the trench slope after earthquake events (Gamo et al., 2007; Kawagucci et al., 2012), this geological force is probably an episodic driver for re-suspension in the IOT. On the other hand, oceanographic forces, such as tidal oscillations and eddy diffusions associated with bottom currents, are weaker but more ubiquitously occurring drivers of re-suspension in the overall deep-sea environment, including the hadal trench. Intense nepheloid bottom layers over the abyssal plain, also generated by sediment re-suspension, have been found in regions where bottom current regimes are both strong and variable (e.g., de Madron et al., 2017). The strong bottom current at the IOT sills (Fujio et al., 2000) combined with the complex seafloor topography of the trench walls (Fig. 1), therefore, likely facilitates re-suspension in the IOT. Nevertheless, the spatiotemporal distribution of the sediment re-suspension events within a trench, magnitudes and durations of the relevant geochemical anomalies in hadal and abyssal waters, and mechanisms driving such re-suspensions remain poorly understood overall.

\subsection{Energetics of the hadal biosphere}

The microbial community inhabiting hadal waters has been shown to be distinct from its abyssal counterpart (Nunoura et al., 2015). For the formation of the hadal biosphere, a certain amount of energy is necessarily required. The minimum energy required to shift one microbial community to another without cell density change should be not lower than the energy to maintain the cell density of the microbial community. The cell-specific energy requirement for "maintenance", when cells only carry out basic metabolic functions and activities without new growth, has been suggested to be $10^{-18} \mathrm{~kJ}$ cell ${ }^{-1} \mathrm{~s}^{-1}\left(=3 \times 10^{-11} \mathrm{~kJ}\right.$ cell $\left.{ }^{-1} \mathrm{yr}^{-1}\right)$ (Hoehler, 2004). On the other hand, the potential energy yield of the IOT hadal-abyssal water through ammonium oxidation can be calculated from the maximum rate esti- 


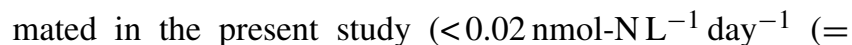
$\left.<7.3 \mathrm{nmol}-\mathrm{NL}^{-1} \mathrm{yr}^{-1}\right)$ ) and the Gibbs free energy of aerobic oxidation of ammonium to nitrate $\left(305 \mathrm{~kJ} \mathrm{~mol}^{-1}-\mathrm{N}\right)$ to be $<2.2 \times 10^{-6} \mathrm{~kJ} \mathrm{~L}^{-1} \mathrm{yr}^{-1}$. An evaluation of the energy potentials for maintenance $\left(3 \times 10^{-11} \mathrm{~kJ} \mathrm{cell}^{-1} \mathrm{yr}^{-1}\right)$ and yield $\left(<2.2 \times 10^{-6} \mathrm{~kJ} \mathrm{~L}^{-1} \mathrm{yr}^{-1}\right)$ indicates that the ammonium oxidation in the hadal-abyssal water column can maintain $<10^{5}$ cell $\mathrm{L}^{-1}$. Since cell densities in the hadal-abyssal water column are typically in the order of $10^{6}$ cell $\mathrm{L}^{-1}$ (e.g., Nunoura et al., 2015), this energetic calculation suggests that, in terms of energy flux, the ammonium oxidation would only occupy a minor role in characterizing the hadal ecosystem. In turn, the oxygen consumption rate in deep Pacific seawater $\left(0.086 \pm 0.003 \mu \mathrm{mol}-\mathrm{O}_{2} \mathrm{~kg}^{-1} \mathrm{yr}^{-1}\right)$, evaluated from the $\Delta^{14} \mathrm{C}-\mathrm{DO}$ relationship (see Sect. 3.4), is approximately 1 order of magnitude higher than the maximum rate possible for the ammonium-oxidation-specific oxygen consumption $\left(<0.018 \mu\right.$ mol- $\left.\mathrm{O}_{2} \mathrm{~kg}^{-1} \mathrm{yr}^{-1}\right)$. If the DO-normalized potential energy yields are the same between aerobic catabolism of deep-sea TOC and ammonium oxidation, the TOC catabolism yields $1.4 \times 10^{-5} \mathrm{~kJ} \mathrm{~kg}^{-1} \mathrm{yr}^{-1}$. This potential energy yield provides a reasonable explanation for the density of microbes observed in the deep-sea water column $\left(\sim 10^{6}\right.$ cell $\left.\mathrm{L}^{-1}\right)$. Although this yield may be insufficient for explaining the rapid turnover of microbial community from the abyssal water community into the hadal biosphere, we are aware that the accurate evaluation of the actual yield requires some more factors to be determined for the hadal water. For example, the in situ oxygen consumption rate in the IOT hadal-abyssal water is assumed to be the same as the Pacific deep-sea-averaged level in the above calculation. As another example, the potential energy yield of TOC catabolism is assumed to be the same as ammonium oxidation in the above calculation. In particular, the oxygen consumption rate is likely higher in the IOT hadal water than the deep Pacific seawater used in the calculation above because sediment re-suspension introduces more labile sedimentary organic compound (Nunoura et al., 2013; Wenzhöfer et al., 2016 ) in addition to the background TOC. The same also applies to the maintenance energy used, which has not been strictly constrained (Hoehler, 2004).

\section{Conclusions}

Using full-depth CTD-CMS observation and sampling, the present study revealed heterogeneous distributions of $\mathrm{CH}_{4}$ within the well-mixed hadal water. We interpret this as meaning that sediment re-suspension, accompanied by the release of sedimentary compounds into the water column, is the most likely source for the $\mathrm{CH}_{4}$ anomaly as well as other geochemical anomalies in the hadal layer reported in previous studies and also observed in the present study. From an energetics viewpoint, microbial ammonium oxidation was shown to only occupy a minor part of the overall microbial oxygen consumption expected in the hadal water column. A great advantage with using the CTD-CMS system to study hadal waters, compared to unconventional methods used in previous studies, is the amount of water that can be sampled using a carousel sampler. The biogeochemical analyses undertaken in this study only used a $\sim 2 \mathrm{~L}$ subsample of a $12 \mathrm{~L}$ seawater sample collected by each Niskin bottle, and the remainder is available for further analyses such as microbiological characterization. To shed the fullest light on the dark hadal biosphere, comprehensive analyses combining hydrography, (bio)geochemistry, and microbiology are indispensable, and full-depth CTD-CMS systems (such as the one available on R/V Kaimei) put such studies within our reach.

Data availability. The dataset reported is available in Table S1 and on-line at http://www.jamstec.go.jp/iorgc/ocorp/data/kate/.

\section{Information about the Supplement}

- Supplement Table S1: all analytical results drawn in figures.

- Supplement Table S2: raw data of nitrification activity measurement.

- Supplement Fig. S1: full-depth profiles.

Supplement. The supplement related to this article is available online at: https://doi.org/10.5194/os-14-575-2018-supplement.

Author contributions. SK, TN, HU, and TY designed the study. AM, TK, YM, CY, EO, MW, and HU conducted chemical and hydrographic analyses. SK, AM, and TY wrote the draft. All authors contributed to sampling and gave final approval for submission and publication.

Competing interests. The authors declare that they have no conflict of interest.

Acknowledgements. The authors thank Katsuhisa Maeno, Yosaku Maeda, the masters, crews, and scientific parties including MWJ and NME staffs of R/V Kaimei cruises (KM16-02, KM16-08, and KM17-01) and a R/V Shinsei-maru cruise (KS-16-8) for their support. Keiko Tanaka, Shoko Tatamisashi, and Yuichiro Kumamoto, respectively, supported the $\mathrm{CH}_{4}$, TOC, and radiocarbon analyses. Chong Chen kindly edited the English of this paper. Konomi Suda, Yuya Tada, Michinari Sunamura, Miho Hirai, and Yoko Sasaki helped subsampling onboard. Kazuya Kitada analyzed and drew seafloor topography. Manganese analyses were supported by Kaiyo Keisoku Co. Ltd. (president: Kei Okamura). 
Edited by: Mario Hoppema

Reviewed by: two anonymous referees

\section{References}

Aoyama, M., Ota, H., Kimura, M., Kitao, T., Mitsuda, H., Murata, A., and Sato, K.: Current Status of Homogeneity and Stability of the Reference Materials for Nutrients in Seawater, Anal. Sci., 28, 911-916, 2012.

Aoyama, M., Abad, M., Anstey, C., Ashraf, P. M., Bakir, A., Becker, S., Bell, S., Berdalet, E., Blum, M., Briggs, R., Caradec, F., Cariou, T., Church, M., Coppola, L., Crump, M., Curless, S., Dai, M., Daniel, A., Davis, C. E., De Santis Braga, E., Solis, M. E., Ekern, L., Faber, D., Fraser, T., Gundersen, K., Jacobsen, S., Knockaert, M., Komada, T., Kralj, M., Kramer, R., Kress, N., Lainela, S., Ledesma, J., Li, X., Lim, J.-H., Lohmann, M., Lonborg, C., Ludwichowski, K.-U., Mahaffey, C., Malien, F., Margiotta, F., Mccormack, T., Murillo, I., Naik, H., Nausch, G., Olafsdottir, S. R., Van Ooijen, J., Paranhos, R., Payne, C., PierreDuplessix, O., Prove, G., Rabiller, E., Raimbault, P., Reed, L., Rees, C., Rho, T., Roman, R., Woodward, E. M. S., Sun, J., Szymczycha, B., Takatani, S., Taylor, A., Thamer, P., TorresValdes, S., Trahanovsky, K., Waldron, H., Walsham, P., Wang, L., Wang, T., White, L., Yoshimura, T. and Zhang, J.-Z. (Eds.): IOCCP-JAMSTEC 2015 Inter-laboratory Calibration Exercise of a Certified Reference Material for Nutrients in Seawater, JAMSTEC, Yokosuka, Japan, 2016.

Beman, J. M., Cheryl-Emiliane, C., King, A. L., Feng, Y., Fuhrman, J. A., Andersson, A., Bates, N. R., Popp, B. N., and Hutchins, D. A.: Global declines in oceanic nitrification rates as a consequence of ocean acidification, P. Natl. Acad. Sci. USA, 108, 208-213, https://doi.org/10.1073/pnas.1011053108, 2011.

Böhlke, J. K., Mroczkowski, S. J., and Coplen, T. B.: Oxygen isotopes in nitrate: new reference materials for ${ }^{18} \mathrm{O}$ : ${ }^{17} \mathrm{O}:{ }^{16} \mathrm{O}$ measurements and observations on nitrate-water equilibration, Rapid Commun. Mass Sp., 17, 1835-1846, https://doi.org/10.1080/10256019808234072, 2003.

Casciotti, K. L.: Nitrogen and Oxygen Isotopic Studies of the Marine Nitrogen Cycle, Annu. Rev. Mar. Sci., 8, 379-407, https://doi.org/10.1146/annurev-marine-010213-135052, 2016.

Casciotti, K. L. and McIlvin, M. R.: Isotopic analyses of nitrate and nitrite from reference mixtures and application to Eastern Tropical North Pacific waters, Mar. Chem., 107, 184-201, 2007.

Casciotti, K. L., Sigman, D. M., Galanter Hastings, M., Böhlke, J. K. and Hilkert, A.: Measurement of the Oxygen Isotopic Composition of Nitrate in Seawater and Freshwater Using the Denitrifier Method, Anal. Chem., 74, 4905-4912, https://doi.org/10.1021/ac020113w, 2002.

Cutter, G. A.: Intercalibration in chemical oceanography-Getting the right number, Limnol. Oceanogr.-Meth., 11, 418-424, https://doi.org/10.4319/lom.2013.11.418, 2013.

de Madron, D. X., Ramondenc, S., Berline, L., Houpert, L., Bosse, A., Martini, S., Guidi, L., Conan, P., Curtil, C., Delsaut, N., Kunesch, S., Ghiglione, J. F., Marsaleix, P., Pujo-Pay, M., Séverin, T., Testor, P., Tamburini, C., and the ANTARES collaboration: Deep sediment resuspension and thick nepheloid layer generation by open-ocean convection, J. Geophys. Res.-Oceans,
122, 2291-2318, https://doi.org/10.1016/j.margeo.2006.10.034, 2017.

Dickson, A.: Determination of dissolved oxygen in sea water by Winkler titration, WOCE Operations Manual, WHPO 91-1, rev. 1, November 1994, Woods Hole Mass., USA, 1996.

Feisthauer, S., Vogt, C., Modrzynski, J., Szlenkier, M., Krüger, M., Siegert, M., and Richnow, H.-H.: Different types of methane monooxygenases produce similar carbon and hydrogen isotope fractionation patterns during methane oxidation, Geochim. Cosmochim. Acta, 75, 1173-1184, https://doi.org/10.1016/j.gca.2010.12.006, 2011.

Fryer, P.: Serpentinite Mud Volcanism: Observations, Processes, and Implications, Annu. Rev. Mar. Sci., 4, 345-373, https://doi.org/10.1146/annurev-marine-120710-100922, 2012.

Fujio, S., Yanagimoto, D., and Taira, K.: Deep current structure above the Izu-Ogasawara Trench, J. Geophys. Res., 105, 63776386, 2000.

Gamo, T. and Shitashima, K.: Chemical characteristics of hadal waters in the Izu-Ogasawara Trench of the western Pacific Ocean, Proc. Jpn. Acad., Ser. B, 94, 45-55, https://doi.org/10.2183/pjab.94.004, 2018.

Gamo, T., Okamura, K., Mitsuzawa, K., and Asakawa, K.: Tectonic pumping: earthquake-induced chemical flux detected in situ by a submarine cable experiment in Sagami Bay, Japan, Proc. Jpn. Acad., Ser. B, 83, 199-204, https://doi.org/10.2183/pjab/83.199, 2007.

Glud, R. N., Wenzhöfer, F., Middelboe, M., Oguri, K., Turnewitsch, R., Canfield, D. E., and Kitazato, H.: High rates of microbial carbon turnover in sediments in the deepest oceanic trench on Earth, Nat. Geosci., 6, 284-288, https://doi.org/10.1038/ngeo1773, 2013.

Granger, J. and Sigman, D. M.: Removal of nitrite with sulfamic acid for nitrate $\mathrm{N}$ and $\mathrm{O}$ isotope analysis with the denitrifier method, Rapid Commun. Mass Sp., 23, 3753-3762, 2009.

Harigane, Y., Michibayashi, K., Morishita, T., Tani, K., Dick, H. J. B., and Ishizuka, O.: The earliest mantle fabrics formed during subduction zone infancy, Earth Planet. Sci. Lett., 377, 106-113, https://doi.org/10.1016/j.eps1.2013.06.031, 2013.

Heuer, V. B., Pohlman, J. W., Torres, M. E., Elvert, M., and Hinrichs, K.-U.: The stable carbon isotope biogeochemistry of acetateand other dissolved carbon species in deep subseafloor sediments at the northern Cascadia Margin, Geochim. Cosmochim. Ac., 73, 3323-3336, https://doi.org/10.1016/j.gca.2009.03.001, 2009.

Hirota, A., Tsunogai, U., Komatsu, D. D., and Nakagawa, F.: Simultaneous determination of $\delta^{15} \mathrm{~N}$ and $\delta^{18} \mathrm{O}$ of $\mathrm{N}_{2} \mathrm{O}$ and $\delta^{13} \mathrm{C}$ of $\mathrm{CH}_{4}$ in nanomolar quantities from a single water sample, Rapid Commun. Mass Sp., 24, 1085-1092, https://doi.org/10.1002/rcm.4483, 2010.

Hoehler, T. M.: Biological energy requirements as quantitative boundary conditions for life in the subsurface, Geobiology, 2, 205-215, 2004.

Holmes, R. M., Aminot, A., Kerouel, R., Hooker, B. A., and Peterson, B. J.: A simple and precise method for measuring ammonium in marine and freshwater ecosystems, Can. J. Fish. Aquat. Sci., 56, 1801-1808, 1999.

Hydes, D., Aoyama, M., Aminot, A., Bakker, K., Becker, S., Coverly, S., Daniel, A., Dickson, A., Grosso, O., Kerouel, R., Van Ooijen, J., Sato, K., Tanhua, T., Woodward, M., and Zhang, J.: 
Determination of dissolved nutrients (N, P, Si) in seawater with high precision and inter-comparability using gas-segmented continuous flow analysers, in: The GO-SHIP Repeat Hydrography Manual: A Collection of Expert Reports and guidelines Version 1, IOCCP Report 14, ICPO Publication Series 134, available at: http://archimer.ifremer.fr/doc/00020/13141/ (last access: June 2018), 2010.

Ichino, M. C., Clark, M. R., Drazen, J. C., Jamieson, A., Jones, D. O. B., Martin, A. P., Rowden, A. A., Shank, T. M., Yancey, P. H., and Ruhl, H. A.: Deep-Sea Res. Pt. I, 100, 21-33, https://doi.org/10.1016/j.dsr.2015.01.010, 2015.

Ishibashi, J., Wakita, H., Okamura, K., Nakayama, E., Feely, R. A., Lebon, G. T., Baker, E. T., and Marumo, K.: Hydrothermal methane and manganese variation in the plume over the superfast-spreading southern East Pacific Rise, Geochim. Cosmochim. Ac., 61, 485-500, 1997.

Jamieson, A. (Ed.): The Hadal Zone - Life in the Deepest Ocean, Cambridge University Press, Cambridge, UK, 2015.

Jamieson, A., Fujii, T., Mayor, D. J., Solan, M., and Priede, I. G.: Hadal trenches: the ecology of the deepest places on Earth, Trends Ecol. Evol., 25, 190-197, 2010.

Kadko, D. C., Rosenberg, N. D., Lupton, J. E., Collier, R. W., and Lilley, M. D.: Chemical reaction rates and entrainment within the Endeavour Ridge hydrothermal plume, Earth Planet. Sc. Lett., 99, 315-335, 1990.

Kawagucci, S., Yoshida, Y. T., Noguchi, T., Honda, M. C., Uchida, H., Ishibashi, H., Nakagawa, F., Tsunogai, U., Okamura, K., Takaki, Y., Nunoura, T., Miyazaki, J., Hirai, M., Lin, W., Kitazato, H.. and Takai, K.: Disturbance of deep-sea environments induced by the M9.0 Tohoku Earthquake, Sci. Rep., 2, 1135, https://doi.org/10.1111/j.1574-6941.2008.00636.x, 2012.

Kawano, T. and Uchida, H. (Eds.): WHP P03 Revisit Data Book, JAMSTEC, Yokosuka, Japan, available at: http://www.jamstec. go.jp/iorgc/ocorp/data/p03rev_2005/ (last access: June 2018), 2007a.

Kawano, T. and Uchida, H. (Eds.): WHP P10 Revisit Data Book, JAMSTEC, Yokosuka, Japan, available at: http://www.jamstec. go.jp/iorgc/ocorp/data/p10rev_2005/ (last access: June 2018), $2007 \mathrm{~b}$.

Kawano, T., Uchida, H., and Doi, T. (Eds.): WHP P01, P14 Revisit Data Book, JAMSTEC, Yokosuka, Japan, available at: http:// www.jamstec.go.jp/iorgc/ocorp/data/p01_p14rev_2007/ (last access: June 2018), 2009.

Kelley, D. S., Karson, J. A., Früh-Green, G. L., Yoerger, D. R., Shank, T. M., Butterfield, D. A., Hayes, J. M., Schrenk, M. O., Olson, E. J., Proskurowski, G., Jakuba, M., Bradley, A., Larson, B., Ludwig, K., Glickson, D., Buckman, K., Bradley, A. S., Brazelton, W. J., Roe, K., Elend, M. J., Delacour, A., Bernasconi, S. M., Lilley, M. D., Baross, J. A., Summons, R. E., and Sylva, S. P.: A Serpentinite-Hosted Ecosystem: The Lost City Hydrothermal Field, Science, 307, 1428-1434, 2005.

Kemeny, P. C., Weigand, M. A., Zhang, R., Carter, B. R., Karsh, K. L., Fawcett, S. E., and Sigman, D. M.: Enzyme-level interconversion of nitrate and nitrite in the fall mixed layer of the Antarctic Ocean, Global Biogeochem. Cy., 30, 1069-1085, https://doi.org/10.1002/2015GB005350, 2016.

Kodama, T., Morimoto, H., Igeta, Y., and Ichikawa, T.: Macroscalewide nutrient inversions in the subsurface layer of Japan Sea during summer, J. Geophys. Res., 120, 7476-7492, 2015.
Komada, T. and Reimers, C. E.: Resuspension-induced partitioning of organic carbon between solid and solution phases from a riverocean transition, Mar. Chem., 76, 155-174, 2001.

Konn, C., Charlou, J. L., Holm, N. G., and Mousis, O.: The Production of Methane, Hydrogen, and Organic Compounds in Ultramafic-Hosted Hydrothermal Vents of the Mid-Atlantic Ridge, Astrobiology, 15, 381-399, https://doi.org/10.1089/ast.2014.1198, 2015.

Kumamoto, Y., Murata, A., Kawano, T., Watanabe, S., and Fukasawa, M.: Decadal changes in bomb-produced radiocarbon in the Pacific ocean from the 1990s to 2000s, Radiocarbon, 55, 16411650, 2013.

Luo, M., Glud, N. R., Pan, B., Wenzhöfer, F., Xu, Y., Lin, G., and Chen, D.: Benthic carbon mineralization in hadal trenches: Insights from in-situ determination of benthic oxygen consumption, Geophys. Res. Lett., 45, 2752-2760, 2018.

Mantyla, A. W. and Reid, J. L.: Measurements of water characteristics at depths greater than $10 \mathrm{~km}$ in the Marianas Trench, DeepSea Res., 25, 169-173, 1978.

McIlvin, M. R. and Casciotti, K. L.: Technical updates to the bacterial method for nitrate isotopic analyses, Anal. Chem., 83, 18501856, https://doi.org/10.1021/ac1028984, 2011.

Morishita, T., Tani, K., Shukuno, H., Harigane, Y., Tamura, A., Kumagai, H., and Hellebrand, E.: Diversity of melt conduits in the Izu-Bonin-Mariana forearc mantle: Implications for the earliest stage of arc magmatism, Geology, 39, 411-414, https://doi.org/10.1130/G31706.1, 2011.

Nozaki, Y. and Ohta, Y.: Rapid and frequent turbidite accumulation in the bottom of Izu-Ogasawara Trench: Chemical and radiochemical evidence, Earth Planet. Sc. Lett., 120, 345-360, 1993.

Nozaki, Y., Yamada, M., Takashi, N., Yutaka, N., Nakamura, K., Shitashima, K., and Tsubota, H.: The distribution of radionuclides and some trace metals in the water columns of the Japan and Bonin trenches, Oceanol. Acta, 21, 469-484, 1998.

Nunoura, T., Nishizawa, M., Kikuchi, T., Tsubouchi, T., Hirai, M., Koide, O., Miyazaki, J., Hirayama, H., Koba, K., and Takai, $\mathrm{K}$.: Molecular biological and isotopic biogeochemical prognoses of the nitrification-driven dynamic microbial nitrogen cycle in hadopelagic sediments, Environ. Microbiol., 15, 3087-3107, https://doi.org/10.1111/1462-2920.12152, 2013.

Nunoura, T., Takaki, Y., Hirai, M., Shimamura, S., Makabe, A., Koide, O., Kikuchi, T., Miyazaki, J., Koba, K., Yoshida, N., Michinari, S., and Takai, K.: Hadal biosphere: Insight into the microbial ecosystem in the deepest ocean on Earth, P. Natl. Acad. Sci. USA, 112, E1230-E1236, https://doi.org/10.1073/pnas.1421816112, 2015.

Oguri, K., Kawamura, K., Sakaguchi, A., Toyofuku, T., Kasaya, T., Murayama, M., Fujikura, K., Glud, R. N., and Kitazato, H.: Hadal disturbance in the Japan Trench induced by the 2011 Tohoku-Oki Earthquake, Sci. Rep., 3, 1915, https://doi.org/10.1038/srep01915, 2013.

Okumura, T., Kawagucci, S., Saito, Y., Matsui, Y., Takai, K., and Imachi, H.: Hydrogen and carbon isotope systematics in hydrogenotrophic methanogenesis under $\mathrm{H}_{2}$-limited and $\mathrm{H}_{2}$ enriched conditions: implications for the origin of methane and its isotopic diagnosis, Progress in Earth and Planetary Science, 3, 14, https://doi.org/10.1186/s40645-016-0088-3, 2016a.

Okumura, T., Ohara, Y., Stern, R. J., Yamanaka, T., Onishi, Y., Watanabe, H. K., Chen, C., Bloomer, S. H., Pujana, I., Sakai, 
S., Ishii, T., and Takai, K.: Brucite chimney formation and carbonate alteration at the Shinkai Seep Field, a serpentinite-hosted vent system in the southern Mariana forearc, Geochem. Geophy. Geosy., 17, https://doi.org/10.1002/2016GC006449, 2016 b.

Popp, B. N., Westley, M. B., Toyoda, S., Miwa, T., Dore, J. E., Yoshida, N., Rust, T. M., Sansone, F. J., Russ, M. E., Ostrom, N. E., and Ostrom, P. H.: Nitrogen and oxygen isotopomeric constraints on the origins and sea-to-air flux of $\mathrm{N}_{2} \mathrm{O}$ in the oligotrophic subtropical North Pacific gyre, Global Biogeochem. Cy., 16, 1064, https://doi.org/10.1029/2001GB001806, 2002.

Reeburgh, W. S.: Oceanic methane biogeochemistry, Chem. Rev., 107, 486-513, 2007.

Resing, J. A., Sedwick, P. N., German, C. R., Jenkins, W. J., Moffett, J. W., Sohst, B. M., and Tagliabue, A.: Basin-scale transport of hydrothermal dissolved metals across the South Pacific Ocean, Nature, 523, 200-203, https://doi.org/10.1016/S00167037(96)00304-3, 2015.

Sarmiento, J. L. and Gruber, N.: Ocean Biogeochemical Dynamics, Princeton University Press, Princeton, 2006.

Shiozaki, T., Ijichi, M., Isobe, K., Hashihama, F., Nakamura, K.I., Ehama, M., Hayashizaki, K.-I., Takahashi, K., Hamasaki, K., and Furuya, K.: Nitrification and its influence on biogeochemical cycles from the equatorial Pacific to the Arctic Ocean, ISME J., 10, 2184-2197, https://doi.org/10.1038/ismej.2016.18, 2016.

Siedler, G., Church, J., and Gould, J. (Eds.): Ocean Circulation and Climate: Observing and Modelling the Global Ocean, Academic Press, London, UK, 2001.

Son, J., Pak, S.-J., Kim, J., Baker, E. T., You, O.-R., Son, S.K., and Moon, J.-W.: Tectonic and magmatic control of hydrothermal activity along the slow-spreading Central Indian Ridge, $8^{\circ} \mathrm{S}-17^{\circ} \mathrm{S}$, Geochem. Geophy. Geosy., 15, 2011-2020, https://doi.org/10.1002/ggge.20243, 2014.

Taira, K.: Super-deep CTD Measurements in the Izu-Ogasawara Trench and a Comparison of Geostrophic Shears with Direct Measurements, J. Oceanogr., 62, 753-758, 2006.

Taira, K., Yanagimoto, D., and Kitagawa, S.: Deep CTD Casts in the Challenger Deep, Mariana Trench, J. Oceanogr., 61, 447454, 2005.

Toki, T., Tsunogai, U., Gamo, T., Kuramoto, S., and Ashi, J.: Detection of low-chloride fluids beneath a cold seep field on the Nankai accretionary wedge off Kumano, south of Japan, Earth Planet. Sci. Lett., 228, 37-47, https://doi.org/10.1016/j.epsl.2004.09.007, 2004.

Toyoda, S., Yoshida, N., Miwa, T., Matsui, Y., Yamagishi, H., Tsunogai, U., Nojiri, Y., and Tsurushima, N.: Production mechanism and global budget of $\mathrm{N}_{2} \mathrm{O}$ inferred from its isotopomers in the western North Pacific, Geophys. Res. Lett., 29, 1037, https://doi.org/10.1029/2001GL014311, 2002.
Toyoda, S., Yoshida, N., and Koba, K.: Isotopocule analysis of biologically produced nitrous oxide in various environments, Mass Spec. Rev., 36, 135-160, https://doi.org/10.1016/j.jinorgbio.2004.09.024, 2017.

Tsunogai, U., Ishibashi, J.-I., Wakita, H., Gamo, T., Watanabe, K., Kajimura, T., Kanayama, S., and Sakai, H.: Peculiar features of Suiyo Seamount hydrothermal fluids, Izu-Bonin Arc: Differences from subaerial volcanism, Earth Planet. Sc. Lett., 126, 289-301, 1994.

Tsunogai, U., Ishibashi, J.-I., Wakita, H., and Gamo, T.: Methanerich plumes in the Suruga Trough (Japan) and their carbon isotopic characterization, Earth Planet. Sc. Lett., 160, 97-105, 1998.

Tsunogai, U., Yoshida, N., Ishibashi, J.-I., and Gamo, T.: Carbon isotopic distribution of methane in deep-sea hydrothermal plume, Myojin Knoll Caldera, Izu-Bonin arc: Implications for microbial methane oxidation in the oceans and applications to heat flux estimation, Geochim. Cosmochim. Ac., 64, 2439-2452, 2000.

Uchida, H., Nakano, T., Tamba, J., Widiatmo, J. V., Yamazawa, K., Ozawa, S., and Kawano, T.: Deep ocean temperature measurement with an uncertainty of $0.7 \mathrm{mK}$, J. Atmos. Ocean. Tech., 32, 2199-2210, 2015.

Uchida, H., Ono, E., Yokokawa, T., and Yanagimoto, D.: Hadal hydrography over the Izu-Ogasawara and Mariana Trenches, in preparation, 2018.

Wakita, M., Honda, M. C., Matsumoto, K., Fujiki, T., Kawakami, H., Yasunaka, S., Sasai, Y., Sukigara, C., Uchimiya, M., Kitamura, M., Kobari, T., Mino, Y., Nagano, A., Watanabe, S., and Saino, T.: Biological organic carbon export estimated from the annual carbon budget observed in the surface waters of the western subarctic and subtropical North Pacific Ocean from 2004 to 2013, J. Oceanogr., 72, 665-685, https://doi.org/10.1007/s10872-016-0379-8, 2016.

Walting, L., Guinotte, J., Clark, M. R., and Smith, C. R.: A proposed biogeography of the deep ocean floor, Prog. Oceanogr., 111, 91112, 2013.

Wenzhöfer, F., Oguri, K., Middelboe, M., Turnewitsch, R., Toyofuku, T., Kitazato, H., and Glud, R. N.: Benthic carbon mineralization in hadal trenches: Assessment by in situ $\mathrm{O}_{2}$ microprofile measurements, Deep-Sea Res. Pt. I, 116, 276-286, https://doi.org/10.1016/j.dsr.2016.08.013, 2016.

Wijffels, S. E., Hall, M. M., Joyce, T., Torres, D. J., Hacker, P., and Firing, E.: Multiple deep gyres of the western North Pacific: A WOCE section along $149^{\circ}$ E, J. Geophys. Res., 103, 1298513009, 1998.

Zhang, J.-Z. and Ortner, P. B.: Effect of thawing condition on the recovery of reactive silicic acid from frozen natural water samples, Water Res., 32, 2553-2555, 1998. 